\title{
Hydrosaline Balance in and Nitrogen Loads from an irrigation district before and after modernization
}

\author{
Jiménez-Aguirre, M. ${ }^{\mathrm{a}}$, Isidoro, D. ${ }^{\mathrm{b}}$ \\ a,b Centro de Investigación y Tecnología Agroalimentaria de Aragón. (CITA). Unidad de Suelos y Riegos \\ (Unidad Asociada EEAD-CSIC). Avenida de Montañana 930, CP 50059 Zaragoza (Spain). \\ a mtjimeneza@cita-aragon.es. Telephone: (+34) 976713832 \\ b disidoro@aragon.es.. Telephone (+34) 976716393 \\ https://doi.org/10.1016/j.agwat.2018.06.008
}

\section{ABSTRACT}

The stress on water resources and the need to maintain water quality and to protect the environment push for an efficient use of natural resources: irrigation water and nutrients (particularly nitrogen). Traditional surface irrigation areas (frequently located on saline materials) use huge amounts of these resources, contributing to the degradation of water bodies by salts and nitrate loads in Irrigation Return Flows (IRF), and also to soil salinization when salt leaching is constrained. In this respect, 1.5 Mha of irrigated lands in Spain have been modernized recently to more efficient systems. Such is the case of the Violada Irrigation District (VID; 4880ha; Northeast Spain) modernized from surface to sprinkler irrigation. The availability of historical data under both irrigation systems in VID offered an ideal scenario to analyze the impact of the modernization process on water consumption and nitrogen management. The analysis was based on the water and salt balances, which showed that irrigation modernization triggered an alteration of the hydrological regime of the VID controlled by the irrigation system. The transformation to sprinkler irrigation resulted in high quality non-diverted water savings of $5536 \mathrm{~m}^{3} / \mathrm{ha} \cdot \mathrm{yr}(19$ $\mathrm{hm}^{3} / \mathrm{yr}$ for the whole VID) available for other uses downstream, triggering a reduction of the IRF from the VID to the Ebro River . In general, the modernization has brought about a clear reduction of all flows in the water balance (except $\mathrm{ET}_{\mathrm{a}}$ ), together with a slight increase in salt and nitrate concentrations in IRF. Both changes entailed a reduction in salt and nitrate loads of $11.5 \mathrm{Mg} / \mathrm{ha} \cdot \mathrm{yr}$ (44889 Mg/yr; -60.4\%) and $82.2 \mathrm{~kg} \mathrm{~N} / \mathrm{ha} \cdot \mathrm{yr}$ (301 Mg N/yr; -70.4\%), respectively. The modernization also resulted in better water use and agronomic indices (drainage fraction, consumptive fraction and irrigation fraction). It was also concluded that at the moment, there is no risk of soil salinization in VID. 


\section{GRAPHICAL ABSTRACT}

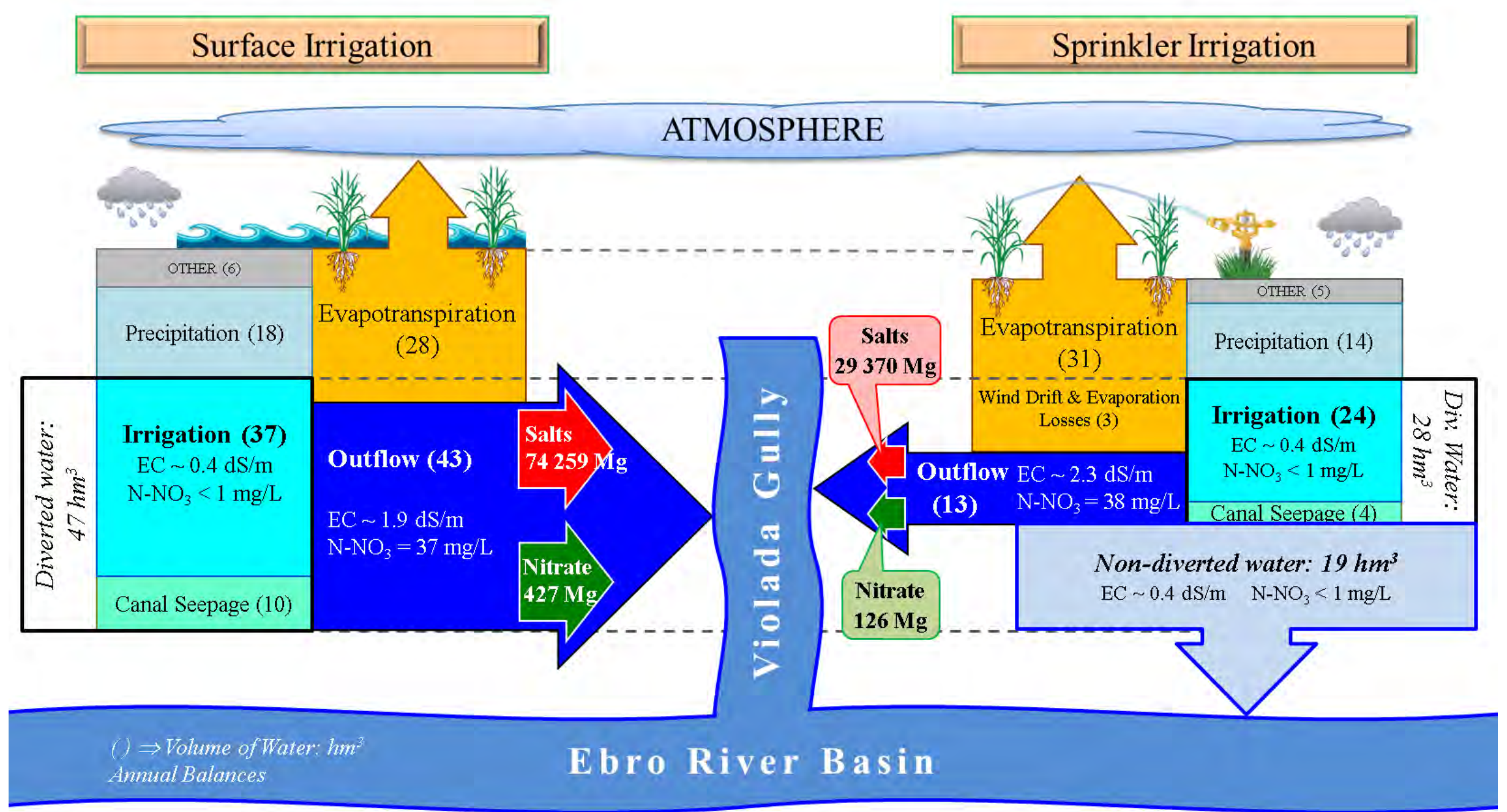




\section{KEYWORDS}

Irrigation Modernization; Irrigation Return Flows; Water quality; Water use; Nitrogen Management; Soil salinization.

\section{ABBREVIATIONS}

AEMET Spanish Meteorological Agency; ANOVA: analysis of the variance; AW: soil water storage; AWUA: Almudévar Water User Association; CF: Consumptive Fraction; CHE: Ebro Basin Authority; CS: Canal Seepage; CU: consumptive use; DF: Drainage Fraction; EC: Electrical Conductivity; $\mathrm{ET}_{0}$ : reference evapotranspiration; $\mathrm{ET}_{\mathrm{a}}$ : Actual Evapotranspiration; FC: Field Capacity; I: Irrigation; IEf : Irrigation Efficiency; IRF: Irrigation Return Flows; IS: Irrigation Season; Ks: Daily Stress Coefficient; LSD: Least Significant Difference test; N: Nitrogen; N-FA: Nitrate Loads Factor Analysis; nIS: NonIrrigation Season; $\mathrm{NL}$ : Nitrate Loads; $\mathrm{N}^{-N_{3}}{ }_{3}^{-}$: Nitrate-Nitrogen; $\mathrm{NO}_{3}{ }^{-}$: Nitrate; $\mathrm{N}_{\mathrm{Q}}$ : Mass of Nitrate-Nitrogen; P: Precipitation; Pef: Effective Precipitation; Q: Drainage Flow; RAW: Readily Available Water; SB: Salt Balance; S-FA: Salt Balance Factor Analysis; SIAR: Agroclimatic Information System for Irrigation; SL: Salt Loads; $\mathrm{S}_{\mathrm{Q}}$ : Mass of Salts; TAW: Total Available Water; TDS: Total Dissolved Solids; VID: Violada Irrigation District; WDEL: Wind Drift and Evaporation Losses; WFD: Water Frame Directive; WP: Wilting Point.

\section{Highlights}

- The modernization of the irrigation system was evaluated with actual data.

- The irrigation system was the main factor controlling Irrigation Return Flows

- Modernization saved high quality non-diverted water, available for other uses.

- Modernization reduced salt and nitrate loads, but increased their concentration.

- Modernization improved the hydrological and agronomic indices. 


\section{INTRODUCTION}

Diffuse pollution and soil salinization are the main environmental problems linked to irrigation lands, especially in semi-arid areas because of water scarcity and the presence of salts. Irrigation may contribute to the salinization of water bodies (off-site effect) through the dissolution of saline materials (frequent in arid and semi-arid zones) and their transport by IRF. In that regard, Aragüés and Tanji (2003) estimated that salt loads to water bodies by Irrigation Return Flows (IRF) ranged between 2 and $20 \mathrm{Mg} /$ ha per year in semi-arid zones. But irrigation may also induce soil salinization (in-situ effect) from the original salty minerals (primary salinization) or, more commonly, from the accumulation of salts provided by irrigation water under limited drainage (secondary salinization). The latter is associated to shallow water tables thus, an appropriate drainage system is the key to ensure the evacuation of the water and salts provided by irrigation (Rhoades, 2011), especially when low water quality is used (EC>3dS/m, Ayers and Westcot, 1985).

In addition, IRF drive huge amounts of nitrogen (in nitrate form) from the intensive, and sometimes excessive, fertilization practices (along with other pollutants, such as

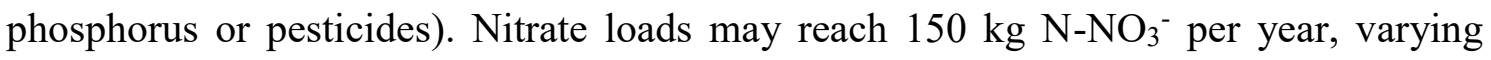
mainly due to the dominant crop, fertilizer practices, and especially, irrigation management (Quemada et al., 2013) and also due to soil type and climatology (Li et al., 2007). The IRF may be reused downstream for irrigation or human consumption, posing a risk for human health (Weisenburger, 1993) as well as for environment: eutrophication of the water bodies (Carpenter et al., 1998) and salinization of irrigated areas (GómezFerrer et al., 1983; Tanji and Kielen, 2002).

On the other hand, irrigation is the backbone of rural development in arid and semi-arid areas, launching the economy (raising crop productivity), ensuring yields and enhancing rural population (FAO, 2002). Thus, the mitigation of pollution is essential, to maintain the balance between fulfillment of human needs and respect for the environment by the correct crop management and the good status of irrigation infrastructures (Thayalakumaran et al., 2007). 
To this ends, the irrigation modernization programs contribute to a better use of water and reduce environmental impacts (Lecina et al. 2010b). On the contrary, better water use efficiency is linked to higher water consumptions at basin level that leads to the so-called "irrigation paradox" based on the Jevons or rebound paradox (Berbel et al., 2015; Rodríguez-Díaz et al., 2011).

In Europe, the Water Framework Directive (WFD; UE, 2000) established the frame for the protection, regulation and management of the aquatic ecosystems, pointing to an efficient and sustainable water use, water withdrawals limitations and reduction of the point and non-point source pollutant loads. As part of the water policy, 1.5 Mha of Spanish irrigated lands have been modernized since 2002 under several governmental national plans (MARM, 2002; MARM, 2006; MARM, 2010) with the same objectives as the WFD of water use efficiency, rural development and conservation of the environmental and natural resources. After all the resources invested on it, the environmental and socio-economic effects of this irrigation modernization process should be analyzed with actual and detailed data from modernized and not-modernized irrigated areas with similar characteristics (Alarcón et al., 2016; Fernández-García et al., 2014).

The availability of historical data since the $80 \mathrm{~s}$ in regard to crop, fertilizer, irrigation and land management at La Violada Irrigation District (VID; Fig. 1), modernized from traditional surface irrigation to sprinkler irrigation; allows for a reliable evaluation of modernization with pre and post modernization data from the same irrigation district and crop management.

Water balance for a given time period (year) is recognized as a fundamental tool for hydrologic characterization and system evaluation, especially if it is influenced by anthropic actions as irrigation. Thus, on irrigation districts, the proper definition of the main water balance flows is essential for the system characterization, along with establishing hydrological indicators and irrigation quality indices (Burt et al., 1997; Perry, 2011). Moreover, the monitoring of salt and nitrate concentrations in those flows will allow setting up the salt balance (SB) and the nitrate loads (NL) at irrigation district level. $\mathrm{SB}$, will provide the key to assess the potential salinization risk in a given irrigation district (Scofield, 1940). 


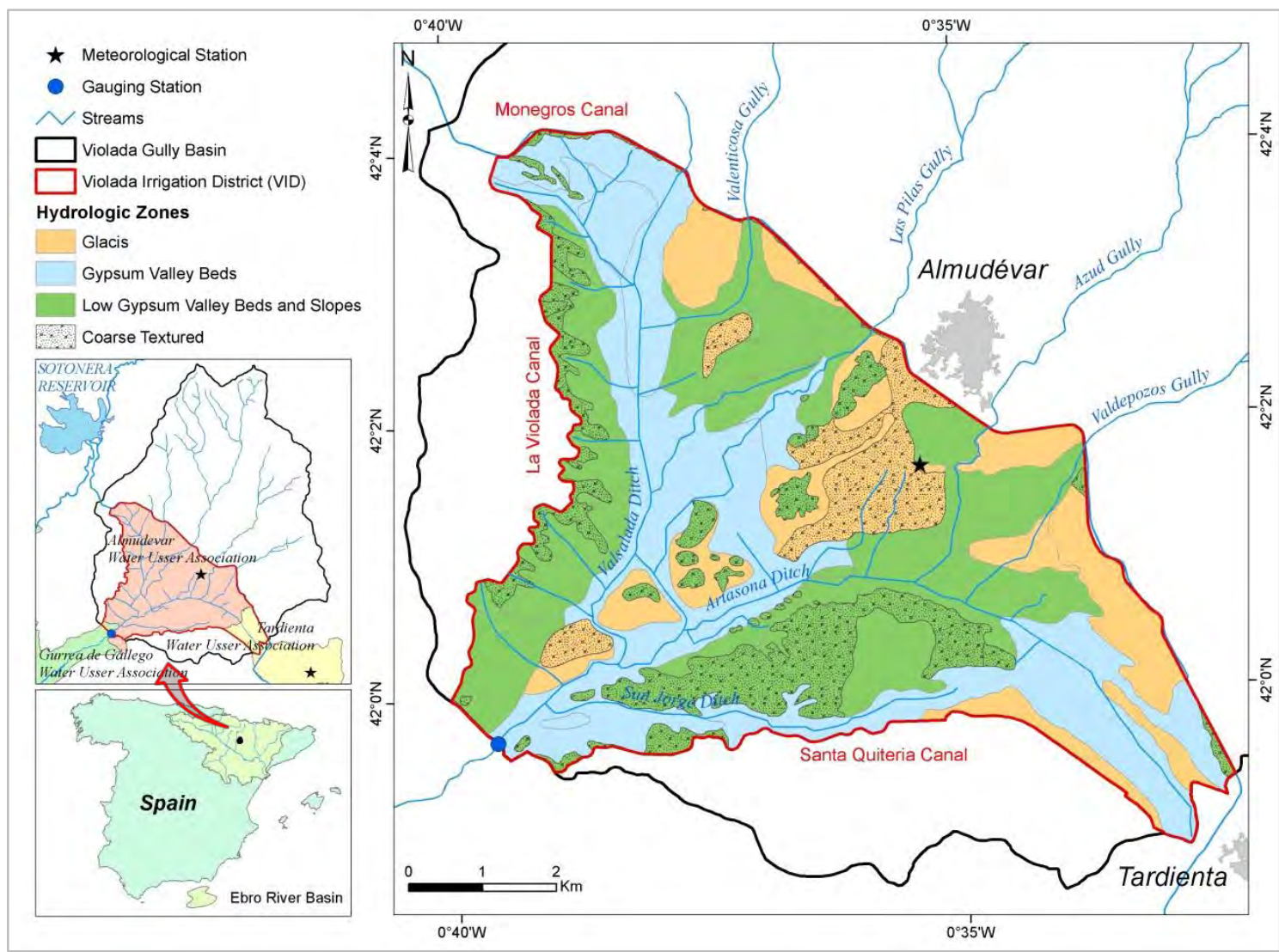

Fig. 1. Location of the Violada Gully Basin and the Violada Irrigation District (VID). Meteorological stations, gauging station and hydrologic zones in VID [from Jiménez-Aguirre et al., (2018b)].

The main objectives of this paper are (i) to quantify the hydrosaline balance and nitrate loads in the irrigation return flows and (ii) to establish the hydrological and irrigation quality indices in VID, before and after the modernization of the irrigation system from surface to sprinkler. The results will allow comparing the IRF from both systems and establishing the impact of the modernization process upon the hydrological regime and pollutant loads.

\section{MATERIAL AND METHODS}

\subsection{Site description}

The VID (Ebro River Basin, in northeast Spain; Fig. 1) covers 5234 ha, of which $92 \%$ (4808 ha) belong to Almudévar Water User Association (AWUA) and the rest to Tardienta and Gurrea de Gállego Water User Associations (7\% and 1\% respectively). The 
VID defines a fairly closed hydrological system, contoured by three concrete irrigation canals (Monegros, La Violada and Santa Quiteria), at higher elevation than the VID. The relief is quite flat (ranging from 345 to $414 \mathrm{~m}$ above sea level) except for some hills within. The soils are mainly characterized by the presence of calcite and gypsum and predominant silty texture all over the VID (Jiménez-Aguirre et al. 2018a; 2018b).

Four gullies flow into the district from the drylands to the northeast and join the drainage network of the VID (Valenticosa, Las Pilas, Azud and Valdepozos Gullies), while the two main drainage ditches collecting the IRF join upstream the gauging station $n^{\circ}$ EA-9230 of the Ebro River Authority (CHE; Fig. 1). Due to an impervious clay layer underlying the district (Faci et al., 1985; ITGE, 1995a, 1995b), deep percolation can be neglected and the only significant water outflows take place through the gauging station. This station allows for quantifying and monitoring the IRF pollutant loads (salts and nitrate) from VID.

Climate is dry, subhumid and mesothermic. Precipitations are concentrated in spring and autumn with an annual average of $458 \mathrm{~mm}$ (data from 1964-2014; Jiménez-Aguirre et al., 2018a). The mean temperature was $13.5^{\circ} \mathrm{C}$ for the same period; the hottest month was July with mean temperature of $22.8^{\circ} \mathrm{C}$ and the coldest was January $\left(5.0^{\circ} \mathrm{C}\right)$. Reference evapotranspiration (ETo; Penman-Monteith) was $1166 \mathrm{~mm}$ for the period of 1995-2008 (Barros et al., 2011a).

\subsection{Irrigation systems}

Irrigation water is diverted from the Gállego River (Ebro River tributary) and distributed through the Monegros Canal (from the Sotonera Reservoir; Fig. 1). It presents excellent quality for irrigation $\left[\mathrm{EC} \sim 0.4 \mathrm{dS} / \mathrm{m},\left[\mathrm{NO}_{3}{ }^{-}\right]<1 \mathrm{mg} / 1\right.$ and $\mathrm{SAR}<1\left(\mathrm{mmol}_{\mathrm{c}} / \mathrm{l}\right)^{0.5}$; Barros et al., 2012a] Since irrigation started in the 1930s, border irrigation prevailed in VID before the modernization. The irrigation system was designed for crops with low-waterneeds (winter grains), with low capacity ditches and leveled basins of small size. The gradual introduction of crops with higher needs (corn and alfalfa) resulted in longer irrigation intervals (around 13 days) and therefore, in low irrigation efficiencies (Faci et al. 2000; Playán et al., 2000). Also, huge water loses took place through canal seepage from the three main irrigation canals (Barros et al., 2011a; Isidoro et al., 2006a). The huge 
irrigation volumes used along with the seepage and the hydrologic characteristics of VID forced farmers to install sub-surface drainage systems since the 1940's (De los Rios, 1966), underlining along time the need for a modernization of irrigation infrastructures.

Modernization works to pressurized irrigation at AWUA, took place in 2008-09, although some infrastructure improvements were made during the 2000s as the new elevated Violada Canal (2003) and the five in-line irrigation reservoirs (1999 to 2005) (Barros et al., 2011a). The modernized sprinkler system in AWUA consists of a pressurized pipe network with 298 hydrants supplied from the reservoirs and scheduled through a remote control system, resulting almost in on-demand irrigation. The works took place after a process of land consolidation to facilitate tillage and cropping operations: the existing land leveling was eliminated and some of the older open drainage lines were buried to increase crop area. This process resulted in a much lower number of plots of greater size (Jiménez-Aguirre, 2017; Stambouli et al., 2014). But, the installation of the buried irrigation lines affected the existing tile-drains, and some farmers have begun the installation of new tile-drains as needed in their plots after 2011 (Gómez-Lanuza, 2016).

Previous studies in VID on water and pollutants and crop management (Barros et al., 2011a, 2011b, 2012a, 2012b; Isidoro et al., 2004, 2006a, 2006b) set up a wide database from 1995-98 and from 2005-08, completed in this work for the years 2009-15. The actual information on crops, water and fertilization management in the VID was provided by the AWUA and Tardienta and Gurrea de Gállego Water User Associations, and their farmers. Those data allow for comparison between surface and sprinkler irrigation in periods with the same dominant crops: corn and alfalfa.

\subsection{Study period}

The study periods comprise the years 1995-98 (90s) for surface irrigation and 2011-15 (10s) for sprinkler irrigation. In both periods, corn was the main crop $(\approx 50 \%$ of the total irrigated area; Table 1) either as a single crop or as double crop for the sprinkler irrigation period; followed by alfalfa $(\approx 20 \%$ ) and cereal (wheat and barley, $\approx 15 \%)$. The dominance of corn (and the generally similar cropping patterns) in both periods allows for comparing the hydrological behavior of the VID under different irrigation systems on equal terms of highly intensive cropping pattern (dominated by corn and alfalfa). 
Additionally, an intermediate pre-works period under surface irrigation was defined in 2005-08 (00s). In those years, the uncertainty about the beginning of the modernization works (and a severe drought in 2005) led to a completely different cropping pattern, under surface irrigation: the dominant crop was alfalfa, followed by cereals with a minor presence of corn (Table 1). Although the main purpose of this paper is the comparison of the high cropping intensity periods $90 \mathrm{~s}$ and $10 \mathrm{~s}$, the pre-works period is also analyzed as it shows the effect of lower cropping intensity and reduced irrigation under the traditional surface irrigation system.

Table 1. Surface area of the main crops in La Violada Irrigation district for the surface irrigation (1995-98), pre-works (2005-07) and sprinkler irrigation (2011-15) periods, with their percentage in regard to the total irrigated area in brackets.

\section{Surface Irrigation (ha) Pre-works (ha) Sprinkler Irrigation (ha)}

\begin{tabular}{|c|c|c|c|}
\hline Crop & $(1995-98)$ & (2005-2007) & $(2011-15)$ \\
\hline Corn & $1967.7(50 \%)$ & $228.2(6 \%)$ & $1104.7(26 \%)$ \\
\hline Double Crops & -- -- & -- -- & $852.6(20 \%)$ \\
\hline Alfalfa & $842.8(21 \%)$ & $1745.1(43 \%)$ & $929.6(22 \%)$ \\
\hline Cereal & $524.0(13 \%)$ & $1297.5(32 \%)$ & $770.9(18 \%)$ \\
\hline Other & $396.6(10 \%)$ & $280.4(7 \%)$ & $258.0(6 \%)$ \\
\hline No Crop & $215.3(5 \%)$ & $461.8(12 \%)$ & $400.0(9 \%)$ \\
\hline Total & 3946.4 & 4013.0 & 4315.8 \\
\hline
\end{tabular}

The first year under sprinkler irrigation (2010) was excluded from the study because winter cereal (59\%) was the dominant crop, a usual practice after transformation, showing a much lower cropping intensity than the proposed 90 s and 10 s periods. Data were also available for years 2008 and 2009, during the modernization works, but these years were also excluded as their cropping intensity was very low (43\% uncropped area).

\subsection{Monthly Water Balance}

A simplified water balance (Eq. [1]) was performed for hydrological years (October to September) where AW represents the increment in soil water storage. The inflows considered were Irrigation (I), Precipitation (P) and Canal Seepage (CS). Minor inflows (surface runoff, municipal waste water and lateral groundwater inflows) were not considered for this work due to their low contribution to the water balance in VID (just $5 \%$ of I+P; Barros et al, 2011a). The outflows considered were the Drainage Flow at the 
gauging station $(\mathrm{Q})$, Actual Evapotranspiration $\left(\mathrm{ET}_{\mathrm{a}}\right)$ and Wind Drift and Evaporation Losses (WDEL). Minor outputs as Groundwater Outflows were considered negligible due to the abovementioned impervious clay layer underneath VID (Faci et al., 1985). All these flows under surface irrigation (for 90s and 00s periods) were characterized by Barros et al. (2011a) and Isidoro et al. (2004) and were completed in this work for the sprinkler irrigation period (10s).

$$
A W=I+P+C S-\left(Q+E T_{a}+W D E L\right)
$$

Daily irrigation (I) was provided by the AWUA and the CHE as daily billed volumes $\left(\mathrm{dam}^{3}\right)$ at the irrigation canal intakes along the three irrigation canals. Meteorological data for all the periods [precipitation $(\mathrm{P} ; \mathrm{mm})$; wind speed $(\mathrm{m} / \mathrm{s})$; relative humidity $(\%)$ ] were collected at the meteorological station $n^{\circ} 9-491$ of the Spanish Meteorological Agency (AEMET) located inside AWUA (Fig. 1). Penman-Monteith reference evapotranspiration $\left(\mathrm{ET}_{0} ; \mathrm{mm}\right)$ was calculated by Barros et al. (2011a) with data from the same meteorological station following FAO Penman-Monteith method (Allen et al., 1998). For the 10s period, the meteorological data (even $\mathrm{ET}_{0}$ ) were retrieved from the SIAR (Agroclimatic Information System for Irrigation) network station at Tardienta, close to the VID (Fig. 1), as this network had more available data since 2009. Eventually, for the analysis of the extreme precipitation event at the early morning of October $20^{\text {th }} 2012$, rainfall data were retrieved again from AEMET, since this station is located inside the VID.

Daily canal seepages $\left(\mathrm{CS} ; \mathrm{m}^{3}\right)$ were determined following the methodology proposed by Barros et al. (2011a), based on the wet surface of Monegros, La Violada and Santa Quiteria canals multiplied by the seepage rate of these canals. Daily records of water level in the canals and their cross-sections (both data provided by CHE) allowed for calculating the wetted perimeter of the canals. Barros et al. (2011a) established a seepage rate of $0.058 \mathrm{~m}^{3} / \mathrm{m}^{2}$. day for the $90 \mathrm{~s}$ and $0.025 \mathrm{~m}^{3} / \mathrm{m}^{2}$. day for the $00 \mathrm{~s}$ and $10 \mathrm{~s}$ from the closing errors of the historical water balances for 1995-2008. As the old, excavated La Violada Canal produced huge water losses due to the deleterious effect of gypsum on concrete (Isidoro et al., 2004), it was replaced by a new elevated canal in 2003. Thus only Monegros and Santa Quiteria canals were considered for CS estimation in the 00s and 10 s periods. 
Daily outflow (Q) was provided by CHE as daily average flows at the gauging station $\left(\mathrm{m}^{3} / \mathrm{s}\right)$. Daily $\mathrm{ET}_{\mathrm{a}}$ and $\mathrm{P}_{\text {ef }}(90 \mathrm{~s}$ and $00 \mathrm{~s}$ periods) were calculated for the main crops in VID (corn, alfalfa and cereal; Table 1) through a soil water balance as described in Barros et al. (2011a). The $E T_{a}$ for those main crops was based on a daily stress coefficient $\left(\mathrm{K}_{\mathrm{s}}\right)$ and daily crop coefficient $\left(\mathrm{K}_{\mathrm{c}} ; \mathrm{ET}_{\mathrm{a}}=\mathrm{K}_{\mathrm{s}} \cdot \mathrm{K}_{\mathrm{c}} \cdot \mathrm{ET}_{\mathrm{C}}\right)$. Coefficients were estimated from daily soil water content in relation to the Readily Available Water (RAW; Allen et al., 1998). RAW was determined as a fraction of Total Available Water (TAW) calculated from hydrological soil parameters (field capacity, wilting point, root depth, coarse fragments and bulk density) determined by Playán et al. (2000) for the whole VID. Daily irrigation information for the main crops were estimated from surveys to local farmers that allowed to stablish irrigation doses, intervals and dates of application. The soil water balance methodology was reproduced for the 10s period introducing double crops and the WDEL as a percentage of daily irrigation calculated from wind speed and relative humidity (Playán et al., 2005).

All fluxes considered (I, P, CS, Q, ET $\mathrm{a}$ and WDEL) were aggregated monthly and converted to $\mathrm{m}^{3} /$ ha of irrigated land considering the irrigated area of each crop in each year. Thus, all fluxes are given as volumes of water per unit of irrigated land.

\subsection{Monthly Salt Balance and Nitrate Loads}

The salt loads ( $\mathrm{SL} ; \mathrm{Mg} / \mathrm{ha}$ ) of all fluxes, that constitute the terms of the salt balance (SB; $\mathrm{Mg} / \mathrm{ha}$ ) (Scofield, 1940), and the nitrate loads (NLQ; $\mathrm{kg} / \mathrm{ha}$ ) at VID, were considered as the product of the daily or monthly flows and the concentrations of either total dissolved solids (TDS; g/L) or nitrate $\left(\mathrm{NO}_{3}{ }^{-} ; \mathrm{mg} / \mathrm{L}\right)$ in each flow, except for $\mathrm{ET}_{\mathrm{a}}$ assumed salt and nitrate free. Each term is settled as follows:

The monthly SB was calculated as the difference between salt inputs and outputs (Eq. [2]). The salt inputs ( $\left.\mathrm{SL}_{\mathrm{IN}}\right)$ considered were irrigation $\left(\mathrm{SL}_{\mathrm{I}}\right)$, precipitation $\left(\mathrm{SL}_{\mathrm{P}}\right)$ and canal seepage $\left(\mathrm{SL}_{\mathrm{CS}}\right)$. The only salt output was outflow drainage at the gauging station $\left(\mathrm{SL}_{\mathrm{Q}}\right)$.

$$
S B(M g / h a)=S L_{I}+S L_{P}+S L_{C S}-S L_{Q}(M g / h a)
$$


The monthly salt inputs $\mathrm{SL}_{\mathrm{I}}, \mathrm{SL}$, and $\mathrm{SL}_{\mathrm{CS}}$ were calculated as the product of each monthly water flow (I, P, and CS), the corresponding TDS, and the required unit conversion factor (Eq. [3]). The monthly input mass of salts ( $\left.\mathrm{S}_{\mathrm{IN}} ; \mathrm{Mg}\right)$ was determined as the product of each SL by the annual irrigated surface.

$$
S L_{(I, P, C S)}(M g / h a)=(I, P, C S)\left(m^{3} / h a\right) \cdot T D S_{(I, P, C S)}(g / L) \cdot 10^{-3}
$$

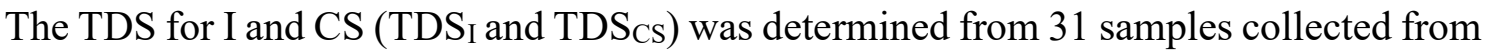
1995 to 1998 (surface irrigation) and 16 samples gathered in 2007-08 (pre-works and sprinkler irrigation periods) from the Monegros Canal. The electrical conductivity (EC) and TDS data at the Monegros Canal, provided by CHE, confirmed that the TDS I $_{\text {has }}$ remained constant since the pre-works period. The TDS of rainfall $\left(\mathrm{TDS}_{\mathrm{P}}\right)$ was taken as the average of 48 samples (gathered 1982-84) for the surface irrigation period and 56 samples (2007-08) for the pre-works and sprinkler irrigation periods. All those values were used in previous studies in the area (Isidoro et al., 2006b and Barros et al 2012b).

The monthly output mass of salts and mass of nitrate $\left(\mathrm{S}_{\mathrm{Q}}\right.$ and $\left.\mathrm{N}_{\mathrm{Q}}\right)$ were determined as the daily product of $\mathrm{Q}$ (in $\mathrm{m}^{3} / \mathrm{s}$ ) and $\mathrm{TDS}_{\mathrm{Q}}$ or $\mathrm{NO}_{3}{ }^{-}$, respectively, and the appropriate unit conversion factor; and then aggregated monthly (Eq.[4]). The monthly salt and nitrogen outputs, $\mathrm{SL}_{\mathrm{Q}}$ and $\mathrm{NL}_{\mathrm{Q}}$, corresponded to the ratio of $\mathrm{S}_{\mathrm{Q}}$ and $\mathrm{N}_{\mathrm{Q}}$ to the annual irrigated surface.

$$
S_{Q}(M g), N_{Q}(k g)=\sum_{\text {days }} Q_{i}\left(m^{3} / s\right) \cdot\left[T D S_{Q i}(g / L), N O_{3 \mathrm{i}}^{-}(m g / L)\right] \cdot 0.0864
$$

The daily TDS at the gauging station $\left(\mathrm{TDS}_{\mathrm{Q}}\right)$ was determined for the surface irrigation and pre-works periods by simple regression between the EC and TDS of 72 samples (Barros et al., 2012b) (Eq. [5]). For sprinkler irrigation, a new regression equation was found from 52 samples taken after the new irrigation system started operation in 2010 (Eq. [6]). In all cases, the TDS was determined as the sum of the dry residue and half the bicarbonate determined by titration (Barros et al, 2012b). 


$$
\begin{gathered}
T D S_{Q}(m g / L)=-441+1150 \cdot E C(d S / m) ; \quad R^{2}=0.92 \quad \text { Year } \leq 2010 \\
T D S_{Q}(m g / L)=951.5 \cdot E C(d S / m) ; \quad R^{2}=0.91 ; \quad \text { Year } \geq 2011
\end{gathered}
$$

The automatic samplers installed at gauging station (Manning S-4040 for the surface irrigation period and ISCO $6712 \mathrm{C}$ for the pre-works and sprinkler irrigation periods) provided a daily water sample taken at noon, solar time. The EC in these samples was measured with two conductimeters: a Radiometer A/S CDM83 in the 90s and an Orion 5 Star in the 00s and 10s. The nitrate concentration $\left(\mathrm{NO}_{3}{ }^{-}, \mathrm{mg} / \mathrm{L}\right)$ in the samples was determined by a 2000isp chromatograph (Dionex, Sunnyvale, CA) in the 90s and with an autoanalyzer (Bran + Luebbe AA3) in the 90s and 10s.

The annual SB corresponds with the sum of the monthly balances. The SB for each period was taken as the average of the annual balances for 1995-98, 2005-07 and 2011-15. The monthly averages of $\mathrm{I}, \mathrm{SB}$ and $\mathrm{NO}_{3}{ }^{-}$for both irrigation systems was also determined in order to assess the impact of irrigation modernization upon their seasonal patterns.

Finally the risk of soil salinization due to insufficient salt leaching (at district level) was analyzed through a simple regression between the annual values of $\mathrm{I}+\mathrm{P}$ and $\mathrm{SB}$ for all years in the three periods.

\subsection{Hydrological indices}

Based on the main components of water balance, three hydrological indices were determined for each study year (1995-98, 2005-08 and 2011-15) and period (average of the years):

1. Drainage Fraction (DF; Eq. [7]): ratio of IRF (difference Q-CS) to water inputs (I+P; other inputs were not considered due to their low contribution; Barros et al., 2012b). This index informs about the fraction of water recovered and susceptible to be reused for human consumption or other agronomical or industrial ends (Perry, 2011). 


$$
D F=\frac{Q-C S}{I+P}
$$

2. Consumptive Fraction (CF; Eq.[8]): ratio of consumptive use $\left(\mathrm{ET}_{\mathrm{a}}+\mathrm{WDEL}\right)$ to water inputs. The CF informs about the water fraction lost to the atmosphere and not available for further use. This index corresponds with the water fraction not returned to watercourses, and lost either as beneficial $\left(\mathrm{ET}_{\mathrm{a}}\right)$ or non-beneficial use (WDEL) (Perry, 2011).

$$
C F=\frac{E T_{a}+W D E L}{I+P}
$$

3. Irrigation Efficiency (IEf; Eq.[9]): ratio of crop consumption satisfied by irrigation $\left(\mathrm{ET}_{\mathrm{a}}-\mathrm{P}_{\mathrm{ef}}\right)$ to total irrigation applied on VID. This index has been adapted from Barros et al. (2011b) and Burt et al. (1997) neglecting the change in soil water storage.

$$
\mathrm{IEf}=\frac{\mathrm{ET}_{\mathrm{a}}-\mathrm{P}_{\mathrm{ef}}}{\mathrm{I}}
$$

The DF and CF were determined for the hydrological year and for the irrigation season (IS, April to September), while the IEf was calculated only for the IS.

\subsection{Statistical procedures}

Differences in annual flows, salt and nitrate loads and hydrological indices between periods were tested by an analysis of the variance (ANOVA), comparing the means by the Least Significant Difference test (LSD). Within each period, different years were taken as different observations. Monthly mean values of $\mathrm{I}, \mathrm{SB}$ and $\mathrm{NO}_{3}{ }^{-}$were also compared through an ANOVA to establish significant differences $(\mathrm{P}<0.05)$ in particular months, and thus possible differences in the annual patterns.

Factor analyses were performed to relate the salt balance (S-FA) and nitrate loads (N-FA) with other crop management variables for the years considered (1995-98, 2005-07 and 
2011-15; 2005 was excluded in N-FA due to incomplete data). The selected variables were the Irrigated area of corn (with double crops included), alfalfa and cereal; I and Q; and the $\mathrm{SB}$ and $\mathrm{TDS}_{\mathrm{Q}}$ for $\mathrm{S}-\mathrm{FA}$ or the $\mathrm{NL}_{\mathrm{Q}}$ and $\mathrm{NO}_{3}{ }^{-}$for N-FA. All of them were standardized and the principal components were rotated by the varimax method to achieve orthogonal factors (Hartman, 1967).

\section{RESULTS AND DISCUSSION}

\subsection{Water Balance}

The terms I and CS of the water balance in VID have decreased significantly from surface irrigation to sprinkler irrigation, whereas $\mathrm{ET}_{\mathrm{a}}$ has increased and a new term WDEL has appeared. No significant differences were found in P.

\subsubsection{Irrigation}

Significant differences $(\mathrm{P}<0.05)$ were found between I under surface irrigation and the other periods (pre-works and sprinkler irrigation), but not between the pre-works and sprinkler periods. The dominance of high water requirements crops as corn and alfalfa and the inefficiency of the obsolete irrigation system, resulted in the highest I of the three periods for surface irrigation: $\mathrm{I}_{90 \mathrm{~s}}=10017 \mathrm{~m}^{3} /$ ha (Table 2).

In the years previous to the modernization works $(00 \mathrm{~s})$, I was reduced by $43 \%\left(\mathrm{I}_{00 \mathrm{~s}}=5665\right.$ $\mathrm{m}^{3} / \mathrm{ha}$ ) in relation to the 90 s mainly due to three factors: (i) a drought in 2005 , which resulted in water restrictions during the next years and in crop pattern changes (more winter grains), (ii) the upgrades in the irrigation system (relining of secondary irrigation canals in AWUA and enforcement by the CHE of the rules regarding the elimination of canal tail waters), and (iii) the uncertainty facing the transformation works (instead of sowing corn, farmers maintained alfalfa in the fields for as long as 7 years, often subirrigated in expectance of the beginning of the works).

When cropping intensity peaked again under sprinkler irrigation (period 10s, with corn as dominant crop and double crops introduced), I rose slightly in regard to the 00 s period to $\mathrm{I}_{10 \mathrm{~s}}=6093 \mathrm{~m}^{3} /$ ha, but was still $39 \%$ lower than in the $90 \mathrm{~s}$. 
Table 2. Main components of the annual water balance in the Violada Irrigation District for the surface irrigation (1995-98), pre-works (2005-08) and sprinkler irrigation (2011-15) periods: Mean $\left(\mathrm{m}^{3} / \mathrm{ha}\right)$, standard deviation $\left(\mathrm{SD} ; \mathrm{m}^{3} / \mathrm{ha}\right)$, coefficient of variation $(\mathrm{CV} ; \%)$ and percent increase over the surface irrigation period $\left(\Delta_{/ 90 s} ; \%\right)$. Different letters mean significant differences between periods $(P<0.05)$.

WATER BALANCE $\left(m^{3} / h a\right)$

\begin{tabular}{|c|c|c|c|c|c|c|c|c|}
\hline \multirow[b]{3}{*}{ Period } & \multicolumn{6}{|c|}{ Inflows } & & \\
\hline & \multicolumn{2}{|c|}{ Irrigation } & \multicolumn{2}{|c|}{ Precipitation } & \multicolumn{2}{|c|}{ Canal Seepages } & \multicolumn{2}{|c|}{ Total Main Inflows } \\
\hline & Mean \pm SD & $\Delta / 90 \mathrm{~s}$ & Mean \pm SD & $\Delta / 90 \mathrm{~s}$ & Mean \pm SD & $\Delta / 90 \mathrm{~s}$ & Mean \pm SD & $\Delta / 90 \mathrm{~s}$ \\
\hline Surface & $10017 \mathrm{a} \pm 686$ & & $4727 \mathrm{a} \pm 1702$ & & $2624 a \pm 40$ & & $17368 \pm 1186$ & \\
\hline Pre-works & $5665 \mathrm{~b} \pm 166$ & $-43 \%$ & $3739 \mathrm{a} \pm 797$ & $-21 \%$ & $1067 b \pm 111$ & $-59 \%$ & $10471 \pm 859$ & $-40 \%$ \\
\hline Sprinkler & $6093 b \pm 270$ & $-39 \%$ & $3611 \mathrm{a} \pm 774$ & $-24 \%$ & $1012 b \pm 48$ & $-61 \%$ & $10716 \pm 956$ & $-38 \%$ \\
\hline
\end{tabular}

Outflows

\begin{tabular}{|c|c|c|c|c|c|c|c|}
\hline \multirow[b]{2}{*}{ Period } & \multicolumn{2}{|l|}{ Drainage } & \multicolumn{2}{|c|}{ Evapotranspiration } & \multicolumn{2}{|c|}{$\begin{array}{c}\text { Wind Drift \& Evap. } \\
\text { Losses }\end{array}$} & $\begin{array}{l}\text { Total Main } \\
\text { Outflows }\end{array}$ \\
\hline & Mean \pm SD & $\Delta_{/ 90 \mathrm{~s}}$ & Mean $\pm \mathrm{SD}$ & $\Delta_{/ 90 \mathrm{~s}}$ & Mean \pm SD & $\Delta_{/ 90 \mathrm{~s}}$ & Mean \pm SD \\
\hline Surface & $11598 \mathrm{a} \pm 575$ & & $7499 \mathrm{a} \pm 244$ & & & & $19096 \pm 748$ \\
\hline Pre-works & $4716 b \pm 772$ & $-59 \%$ & $6087 b \pm 413$ & $-19 \%$ & & & $10803 \pm 833-43 \%$ \\
\hline Sprinkler & $3377 b \pm 1429$ & $-71 \%$ & $7803 \mathrm{a} \pm 669$ & $4 \%$ & $772 \pm 50$ & -- & $11952 \pm 1965-37 \%$ \\
\hline
\end{tabular}

Other similar irrigation districts in the middle Ebro River Basin showed results consistent with these: García-Garizábal and Causapé (2010) determined an average irrigation contribution about $9600 \mathrm{~m}^{3} /$ ha under surface irrigation (with alfalfa as dominant crop followed by corn) while Tedeschi et al. (2001) found a value of $7035 \mathrm{~m}^{3} / \mathrm{ha}$ in a new sprinkler irrigation district established in 1992 (with corn as dominant crop followed by alfalfa).

Monthly irrigation decreased significantly under sprinkler irrigation in relation to surface irrigation in April and summer months (June to September; Fig. 2a). Pre-sowing irrigations were usual in April with surface irrigation, in order to prepare fields for corn cultivation and facilitate plant emergence by minimizing soil crusting. Those irrigations disappeared in pre-works period due to changes in crop patterns to alfalfa. The general practice of no-tillage seeding under sprinkler irrigation (which reduces soil crusting problems) allowed for eliminating pre-sowing irrigations or reducing them to very low doses and frequencies. 


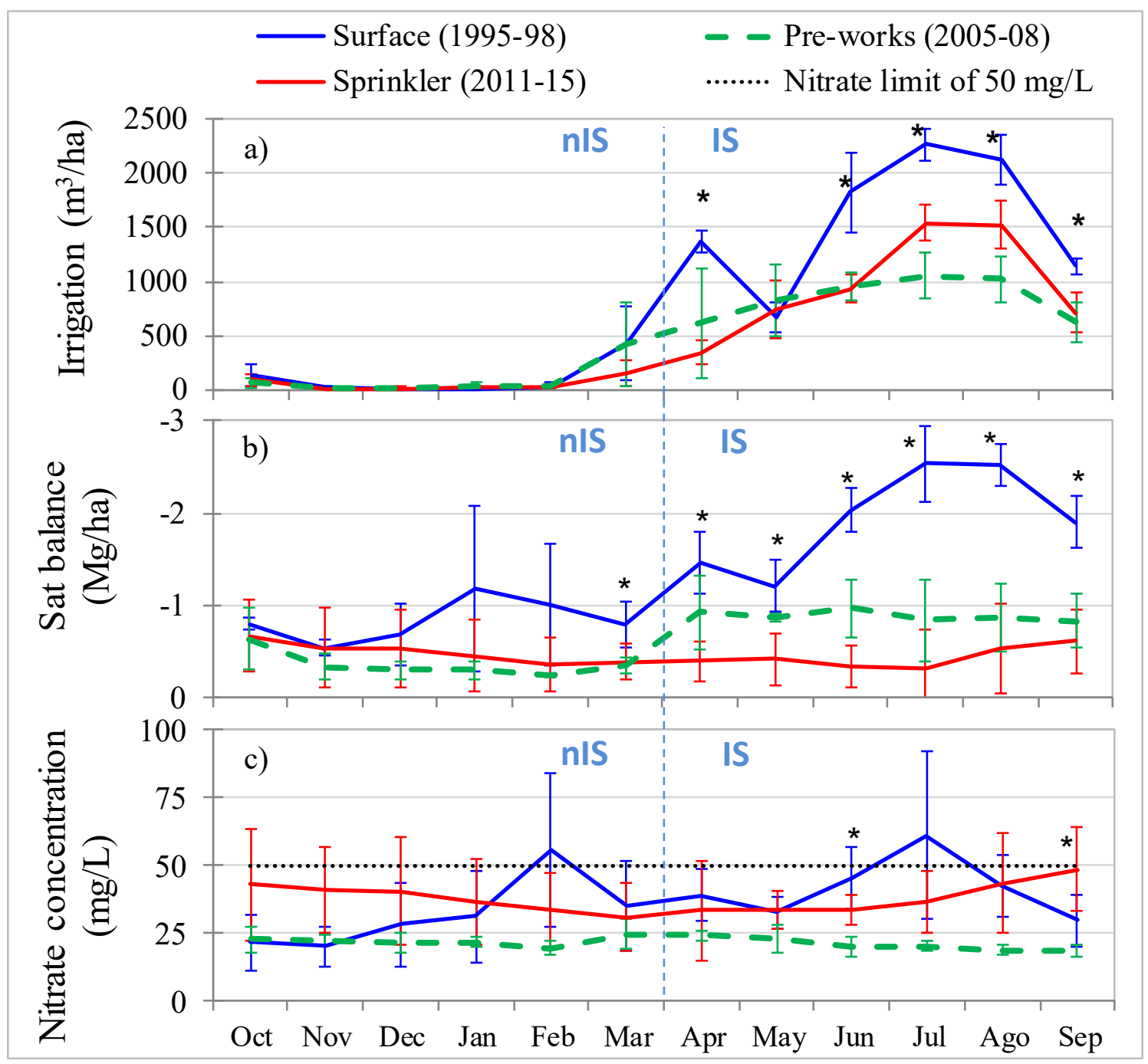

Fig. 2. Monthly average of a) applied irrigation; $b$ ) salt balance in VID; and c) drainage nitrate concentration measured at the gauging station in La Violada Gully in the 3 periods considered. Asterisks mark the months with significant differences $(P<0.05)$ between surface and sprinkler irrigation periods.

In the whole, the total water depletion from Monegros Canal in VID has decreased by $36 \%$ from $37.4 \mathrm{hm}^{3} / \mathrm{yr}$ to $23.9 \mathrm{hm}^{3} / \mathrm{yr}$ (Table 3), when comparing the two high intensity corn cultivation periods (90s and 10s), leading a water save for other uses downstream the Monegros Canal, of $13.5 \mathrm{hm}^{3} / \mathrm{yr}$. 
Table 3. Main components of the water balance and total consumptive use $\left(\mathrm{hm}^{3} / \mathrm{yr}\right)$ in the Violada Irrigation District for the Non Irrigation Season, Irrigation Season (seasonal percentage in brackets), and hydrologic year of the surface irrigation (1995-98), pre-works (2005-08) and sprinkler irrigation (2011-15) periods and percent increase over the surface irrigation period $(\Delta / 90 s \%)$.

WATER VOLUMES $\left(\mathrm{hm}^{3} / \mathrm{yr}\right)$

\begin{tabular}{|c|c|c|c|c|}
\hline Period & $\begin{array}{c}\text { Non Irrigation } \\
\text { Session }\end{array}$ & Irrigation Session & Annual & $\Delta_{/ 90 \mathrm{~s}}$ \\
\hline \multicolumn{5}{|l|}{ Inflows: } \\
\hline \multicolumn{5}{|l|}{ Irrigation (I) } \\
\hline Surface & $2.3(6 \%)$ & $35.1(94 \%)$ & 37.4 & \\
\hline Pre-works & $2.0(10 \%)$ & $18.2(90 \%)$ & 20.2 & $-46.1 \%$ \\
\hline Sprinkler & $1.2(5 \%)$ & $22.7(95 \%)$ & 23.9 & $-36.2 \%$ \\
\hline \multicolumn{5}{|c|}{$\begin{array}{l}\text { Canal Seepages }(\mathrm{CS}) \\
\text { (a) }\end{array}$} \\
\hline Surface & $4.5(46 \%)$ & $5.3(54 \%)$ & 9.8 & \\
\hline Pre-works & $1.7(44 \%)$ & $2.1(56 \%)$ & 3.8 & $-61.6 \%$ \\
\hline Sprinkler & $1.9(47 \%)$ & $2.1(53 \%)$ & 4.0 & $-59.5 \%$ \\
\hline \multicolumn{5}{|l|}{ Outflows: } \\
\hline \multicolumn{5}{|l|}{ Drainage $(\mathbf{Q})$} \\
\hline Surface & $12.4(29 \%)$ & $30.9(71 \%)$ & 43.3 & \\
\hline Pre-works & $4.5(26 \%)$ & $12.4(74 \%)$ & 16.9 & $-60.9 \%$ \\
\hline Sprinkler & $5.9(44 \%)$ & $7.4(56 \%)$ & 13.3 & $-69.3 \%$ \\
\hline \multicolumn{5}{|c|}{ Evapotranspirtion $\left(\mathbf{E T}_{\mathrm{a}}\right)$} \\
\hline Surface & $4.4(16 \%)$ & $23.6(84 \%)$ & 28.0 & \\
\hline Pre-works & $4.4(20 \%)$ & $17.2(80 \%)$ & 21.7 & $-22.5 \%$ \\
\hline Sprinkler & $6.1(20 \%)$ & $24.4(80 \%)$ & 30.6 & $+9.2 \%$ \\
\hline \multicolumn{5}{|c|}{ Wind Drift \& Evap. Losses (WDEL) } \\
\hline Sprinkler & $0.1 \quad(2 \%)$ & $2.9(98 \%)$ & 3.0 & -- \\
\hline \multicolumn{5}{|c|}{ Consumtpive Use $\left(\mathbf{E T}_{\mathrm{a}}+\right.$ WDEL$)$} \\
\hline Surface & $4.4(16 \%)$ & $23.6(84 \%)$ & 28.0 & \\
\hline Pre-works & $4.4(20 \%)$ & $17.2(80 \%)$ & 21.7 & $-22.5 \%$ \\
\hline Sprinkler & $6.2(18 \%)$ & $27.4(82 \%)$ & 33.6 & $+20.0 \%$ \\
\hline
\end{tabular}




\subsubsection{Canal Seepage}

Significant differences in CS were found between the 90s and both the 00s and 10s due to the rebuilt of the elevated canal of La Violada in 2003. During the surface irrigation period, CS were determined as $\mathrm{CS}_{90 \mathrm{~s}}=2624 \mathrm{~m}^{3} /$ ha $($ Table 2$)$ or $9.8 \mathrm{hm}^{3} / \mathrm{yr}$ (Table 3), the vast majority because of the degradation of concrete in the canals by the gypsum present in the VID soils (Barros et al., 2011a; Llamas, 1962; Isidoro et al., 2004, 2006a; JiménezAguirre et al., 2018a). After the construction of the new Violada canal, CS were considered to originate only from the Monegros and Santa Quiteria canals (the latter only at its non-elevated section of $5.4 \mathrm{~km})$ and reduced to $\mathrm{CS}_{00 \mathrm{~s}}=1067 \mathrm{~m}^{3} / \mathrm{ha}(-59 \%)$ or $3.8 \mathrm{hm}^{3} / \mathrm{yr}$.

After the modernization, although some maintenance works were performed at the Monegros and Santa Quiteria canals, CS remained fixed in regard to the pre-works period: $\mathrm{CS}_{10 \mathrm{~s}}=1012 \mathrm{~m}^{3} /$ ha $(61 \%$ lower than in the surface irrigation period, Table 2$)$ or $4.0 \mathrm{hm}^{3} / \mathrm{yr}$ (Table 3), leading to water saving of $5.8 \mathrm{hm}^{3} / \mathrm{yr}$.

\subsubsection{Outflow}

Outflow drainage at the gauging station $(\mathrm{Q})$ showed significant differences $(\mathrm{P}<0.05)$ between surface irrigation and the other two periods, without differences between them (Table 2). Throughout the $90 \mathrm{~s}$, the average outflow was $\mathrm{Q}_{90 \mathrm{~s}}=11598 \mathrm{~m}^{3} /$ ha, equivalent to $43.3 \mathrm{hm}^{3} / \mathrm{yr}$ (Table 3 ). About $71 \%$ of this volume $\left(30.9 \mathrm{hm}^{3} / \mathrm{yr}\right)$ took place during the irrigation season (IS) and just $29 \%$ during the non-irrigation season (nIS). At the following pre-works period, Q decreased by $59 \%\left(\mathrm{Q}_{00 \mathrm{~s}}=4716 \mathrm{~m}^{3} / \mathrm{ha}\right)$ due to the reduction in I, but the annual outflow pattern remained similar to the 90s: higher during the IS $\left(12.4 \mathrm{hm}^{3} / \mathrm{yr} ; 74 \%\right.$ of the outflow volume) than the nIS (26\%) (Table 3$)$.

The downward trend observed in Q (produced by the lower I) continued during the sprinkler irrigation period with $\mathrm{Q}_{10 \mathrm{~s}}=3377 \mathrm{~m}^{3} / \mathrm{ha}(-71 \%)$ but with higher variability $\left( \pm 1429 \mathrm{~m}^{3} / \mathrm{ha}\right.$; Table 2$)$ in contrast to the previous periods $\left( \pm 575 \mathrm{~m}^{3} / \mathrm{ha}\right.$ and $\left.\pm 772 \mathrm{~m}^{3} / \mathrm{ha}\right)$. As total volume, the outflow through the gauging station decreased to $13.3 \mathrm{hm}^{3} / \mathrm{yr}$ in the $10 \mathrm{~s}, 69 \%$ lower in regard to surface irrigation (Table 3). This decrease took place mainly during the IS (due to changes in I) with $7.4 \mathrm{hm}^{3} / \mathrm{yr}$ compared to $30.9 \mathrm{hm}^{3} / \mathrm{yr}$ in the $90 \mathrm{~s}$ (Table 3). Outflow during the IS accounted for $56 \%$ of the annual outflow, almost equal 
to nIS outflow ( $5.9 \mathrm{hm}^{3} / \mathrm{yr}$ or $44 \%$ ). So the change to sprinkler irrigation has changed the annual outflow patterns: while around 3/4 of the outflow took place during the IS under surface irrigation, under sprinkler irrigation this fraction reduced to around $50 \%$. That implies a significant reduction of the environmental impact during the low flow season, most sensitive to pollution. Tedeschi et al. (2001) obtained similar results in another sprinkler irrigated district in the middle Ebro River Basin.

The origin of the variability in the $\mathrm{Q}_{10 \mathrm{~s}}$ (high SD) was the torrential rain on October $20^{\text {th }}$ 2012 (the beginning of the 2013 hydrological year). During the early morning $144 \mathrm{~mm}$ were registered at the meteorological station of AEMET (Fig. 1) and the subsequent flooding of $7.42 \mathrm{~m}^{3} / \mathrm{s}$ overflew the gauging station. This extraordinary rainfall has led to an increase in Q and salt load, sustained in time until now, as will be seen in the following sections.

\subsubsection{Actual Evapotranspiration and Wind Drift and Evaporation Losses}

The $\mathrm{ET}_{\mathrm{a}}$ was significantly lower $(\mathrm{P}<0.05)$ in the pre-works period than under surface or sprinkler irrigation (with no differences among them) due to the lower cropping intensity. Under surface irrigation, corn accounted for $50 \%$ of $\mathrm{ET}_{\mathrm{a}-90 \mathrm{~s}}=7499 \mathrm{~m}^{3} /$ ha (Table 2) equivalent to $28.0 \mathrm{hm}^{3} / \mathrm{yr}$ (Table 3); while alfalfa accounted for $21 \%$. During the preworks period, $\mathrm{ET}_{\mathrm{a}}$ decreased by $19 \%\left(\mathrm{ET}_{\mathrm{a}-00 \mathrm{~s}}=6087 \mathrm{~m}^{3} / \mathrm{ha}\right)$ due to the new crop pattern (corn $6 \%$, alfalfa $43 \%$ and cereal $32 \%$ ).

When cropping intensity recovered under sprinkler irrigation, the $\mathrm{ET}_{\mathrm{a}}$ slightly increased by $4 \%$ in regard to surface irrigation to $\mathrm{ET}_{\mathrm{a}-10 \mathrm{~s}}=7836 \mathrm{~m}^{3} / \mathrm{ha}$, equivalent to $30.6 \mathrm{hm}^{3} / \mathrm{yr}$. This meant an increase of $9.2 \%$ (Table 3) in crop evapotranspiration, beneficial consumption (Perry, 2011), from surface to sprinkler irrigation. In addition, the new component WDEL $=772 \mathrm{~m}^{3} /$ ha (not beneficial consumption; Table 2) increased the consumptive use (CU) in VID in $3 \mathrm{hm}^{3} / \mathrm{yr}$, up to $\mathrm{CU}_{10 \mathrm{~s}}=33.6 \mathrm{hm}^{3} / \mathrm{yr}$ (a $20 \%$ increase in relation to $\mathrm{CU}_{90 \mathrm{~s}}$ ) (Table 3).

As corn is the most sensitive crop to water stress in VID, the use of shorter irrigation intervals under sprinkler irrigation was expected to lead to an increase in calculated $\mathrm{ET}_{\mathrm{a}}$ (Barros et al., 2011b; Lecina 2010b; Playán and Mateos, 2006). Nevertheless, the observed increase in $\mathrm{ET}_{\mathrm{a}}$ under the new system took place during the nIS (Table 3), 
pointing to cereals as the main responsible for this rise instead of corn. These results suggest the possible underestimation at $\mathrm{ET}_{\mathrm{a}}$ calculation for sprinkler irrigation period (or, less likely, an overestimation for previous periods). An accurate determination of $\mathrm{ET}_{\mathrm{a}}$ is essential for the water balance determination as $\mathrm{ET}_{\mathrm{a}}$ is one of the main components of the balance (Clemmens, 2009).

Allen et al. (2005) pointed to the predictions of evaporation form wet soil, among others, as a possible source of inaccuracy in $\mathrm{ET}_{\mathrm{a}}$ determinations. In that regard, the daily soil water balances used for annual $\mathrm{ET}_{\mathrm{a}}$ calculation, might be improved by using distributed actual daily irrigation information (now available from the remote control system) with the hydrologic properties (Field Capacity -FC- and Wilting Point -WP) measured for each soil unit (Jiménez-Aguirre et al., 2018b), instead of using average FC and WP values for the whole VID (Barros et al., 2011a).

\subsection{Salt Balance}

\subsubsection{Total Dissolved Solids in the outflow}

The TDS $_{\mathrm{Q}}$ under surface irrigation $\left(\mathrm{TDS}_{\mathrm{Q}-90 \mathrm{~s}}=1.7 \mathrm{~g} / \mathrm{L}\right.$; Table 4) was significantly different from the pre-works $\left(\mathrm{TDS}_{\mathrm{Q}-00 \mathrm{~s}}=2.0 \mathrm{~g} / \mathrm{L}\right)$ and from the sprinkler irrigation $\left(\mathrm{TDS}_{\mathrm{Q}-10 \mathrm{~s}}=2.2 \mathrm{~g} / \mathrm{L}\right)$ periods. Those differences implied an increase by $16 \%(00 \mathrm{~s})$ and by $26 \%$ (10s) in relation to the $90 \mathrm{~s}$. Those increases owed to the lower diluting flows in the VID (canal seepage and tail-waters). However, the EC always remained close to EC $=2$ $\mathrm{dS} / \mathrm{m}$ (data not presented) due to gypsum dissolution. The gypsum in the original material is dissolved by drainage flows causing the IRF to be (almost) saturated in gypsum (Jiménez-Aguirre et al, 2018a; 2018b), maintaining a fairly constant EC (Isidoro et al., 2006a) and therefore constant TDS $_{Q}$ (Fig. 3).

During the sprinkler irrigation period, the torrential rain on October 2012 gave rise to two distinct phases on $\mathrm{TDS}_{\mathrm{Q}}$, possibly by salt mobilization from deep saline layers or saline water tables. Before the precipitation event (2011-12), TDS $_{\mathrm{Q}}$ had decreased to $1.8 \mathrm{~g} / \mathrm{L}$ (Fig. 3), close to the value in the 90s. After the event (2013-15), TDS $_{Q}$ rose to $2.3 \mathrm{~g} / \mathrm{L}$. Such high values were registered 30 years ago by Faci et al. (1985) in VID. The high percolation in those years (1980-82), derived from the inefficient irrigation system, may have been mobilizing salts from deep layers resulting in higher $\mathrm{TDS}_{\mathrm{Q}}$, and this 
mobilization was not found again until the extraordinary precipitation event of October 2012. Thayalakumaran et al. (2007) pointed out that, extreme climatic events producing floods may cause long term lateral and vertical salt mobilizations in the soil at all spatial scales, which is consistent with the high $\mathrm{TDS}_{\mathrm{Q}}$ found in the following study years (2014-15).

Table 4. Main components of the salt balance in VID: mean (Mg/ha; different letters mean significant differences between periods, $P<0.05)$ and standard deviation $(S D ; M g / h a)$ for the surface irrigation (1995-98), pre-works (2005-07) and sprinkler irrigation (2011-15) periods; and percent increase over the surface irrigation period $\left(\triangle_{/ 90 s} ; \%\right)$. The TDS of the outflow $\left(T D S_{Q}\right.$; $\mathrm{g} / \mathrm{L})$ for each period are also shown.

SALT BALANCE $(M g / h a)$

\begin{tabular}{|c|c|c|c|c|c|c|c|}
\hline \multirow[b]{2}{*}{ Period } & Irrigation $\left(S L_{I}\right)$ & \multicolumn{2}{|c|}{ Precipitation $\left(S L_{P}\right)$} & \multicolumn{3}{|c|}{$\begin{array}{c}\text { Canal Seepages } \\
\left(S L_{C S}\right)\end{array}$} & Salt Inflow $\left(S L_{I N}\right)$ \\
\hline & Mean $\pm \mathrm{SD} \Delta_{/ 90 \mathrm{~s}}$ & $\overline{\text { Mean }} \pm \mathrm{SD}$ & $\Delta / 90 \mathrm{~s}$ & Mean & $\pm \mathrm{SD}$ & $\Delta_{/ 90 \mathrm{~s}}$ & Mean $\pm \mathrm{SD} \quad \Delta_{/ 90 \mathrm{~s}}$ \\
\hline Surface & $2.3 \pm 0.2$ & $0.3 \pm 0.1$ & -- & & \pm 0.0 & -- & $3.2 \mathrm{a} \pm 0.1$ \\
\hline Pre-works & $1.4 \pm 0.0-41 \%$ & $0.2 \pm 0.0$ & $-33 \%$ & & \pm 0.0 & $-57 \%$ & $1.8 b \pm 0.1-43 \%$ \\
\hline Sprinkler & $1.5 \pm 0.1-36 \%$ & $0.2 \pm 0.0$ & $-35 \%$ & 0.2 & \pm 0.0 & $-60 \%$ & $1.9 b \pm 0.1-41 \%$ \\
\hline
\end{tabular}

\begin{tabular}{|c|c|c|c|c|c|}
\hline \multirow[b]{2}{*}{ Period } & \multicolumn{2}{|c|}{$T D S_{Q}(g / L)$} & \multicolumn{2}{|c|}{ Salt Outflow $\left(S L_{Q}\right)$} & Salt Balance $(\mathrm{SB})$ \\
\hline & Mean \pm SD & $\Delta_{/ 90 \mathrm{~s}}$ & Mean \pm SD & $\Delta / 90 \mathrm{~s}$ & Mean $\pm \mathrm{SD} \Delta_{/ 90 \mathrm{~s}}$ \\
\hline Surface & $1.7 \mathrm{a} \pm 0.2$ & -- & $19.9 \mathrm{a} \pm 1.9$ & -- & $-16.7 a \pm 1.9$ \\
\hline Pre-works & $2.0 \mathrm{~b} \pm 0.1$ & $16 \%$ & $9.3 \mathrm{~b} \pm 1.2$ & $-53 \%$ & $-7.5 b \pm 1.2-55 \%$ \\
\hline Sprinkler & $2.2 \mathrm{c} \pm 0.2$ & $26 \%$ & $7.5 b \pm 3.5$ & $-68 \%$ & $-5.6 b \pm 3.4-66 \%$ \\
\hline
\end{tabular}

During the pre-works period and the first years after transformation (2010-12), the leaching fraction decreased due to the decrease in I (and Q). This lower leaching and possible salt accumulation, due to the partial destruction of the drainage network (for sprinkler installation), may produce salt stocks in the system which the precipitation event started leaching, increasing again $\mathrm{TDS}_{\mathrm{Q}}$ and overlapping with the full recovery of corn intensity at hydrological year 2013 (higher I and Q). This disruption in the SB has remained constant until now, calling for the monitoring of its future trends, either if it is maintained or if it decreases to a new equilibrium. 


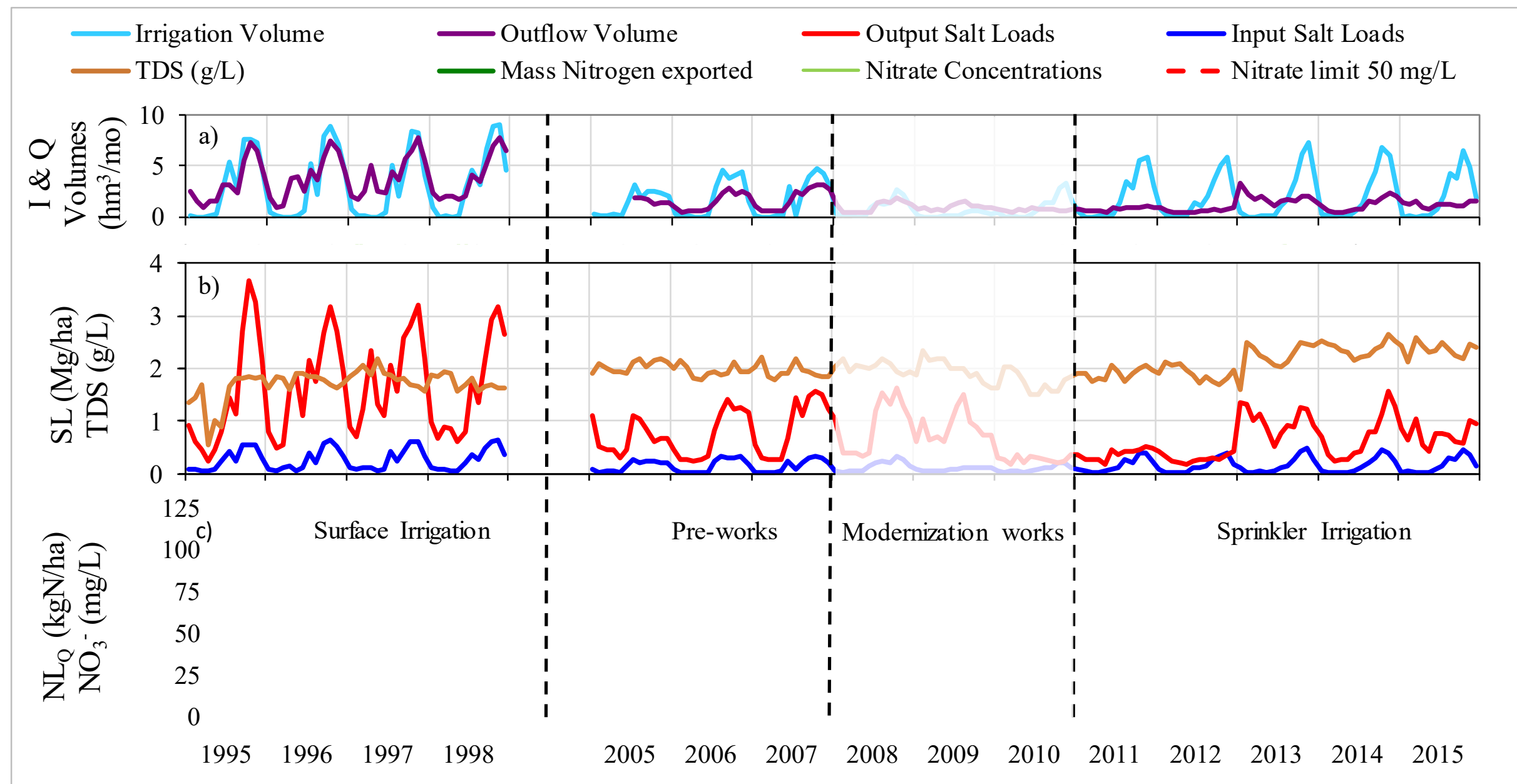

Fig. 3. Monthly average of a) Irrigation (I) and Outflow (Q); b) Total Dissolved Solids (TDS) and Input and Output Salt Loads (SL); and c) Nitrate Loads (NL $\left.L_{Q}\right)$ and Outflow Nitrate Concentration ( $\left.\mathrm{NO}_{3}^{-}\right)$in VID for the surface irrigation (1995-98), pre-works (2005-08) and sprinkler irrigation (2011-15) periods. Data for the modernization works period (2008-10; not presented in the text) are also shown. 


\subsubsection{Salt inputs and outputs}

Inflow and outflow salt loads ( $\mathrm{SL}_{\mathrm{IN}}$ and $\mathrm{SL}_{\mathrm{Q}}$; Fig. 3) have shown significant differences $(\mathrm{P}<0.05)$ between the 90 s period and the 00s and 10s, without differences between them. During surface irrigation $\mathrm{SL}_{\mathrm{IN}-90 \mathrm{~s}}=3.2 \mathrm{Mg} / \mathrm{ha}$ (Table 4) was mainly produced by high I and CS, despite the excellent quality of the Monegros Canal water (Barros et al., 2012b). During pre-works period $\mathrm{SL}_{\mathrm{IN}-00 \text { s }}$ dropped by $43 \%$ to $1.8 \mathrm{Mg} / \mathrm{ha}$, and sprinkler irrigation entailed a reduction by $41 \%$ to $\mathrm{SL}_{\mathrm{IN}-10 \mathrm{~s}}$ to $1.9 \mathrm{Mg} / \mathrm{ha}$ (in regard to surface irrigation), a reduction slightly lower than in pre-works period due to the increase in I from the 00 s to the $10 \mathrm{~s}$.

Outflow salt loads under surface irrigation amounted to $\mathrm{SL}_{\mathrm{Q}-90 \mathrm{~s}}=19.9 \mathrm{Mg} / \mathrm{ha}$ (Table 4). These loads represented a salt contribution to La Violada Gully of $\mathrm{S}_{\mathrm{Q}-90 \mathrm{~s}}=74259 \mathrm{Mg} / \mathrm{yr}$ mainly during the IS (72\%; $\mathrm{S}_{\mathrm{Q}-\mathrm{IS}-90 \mathrm{~s}}=53443 \mathrm{Mg} / \mathrm{yr}$; Table 5). During the pre-works period, salt loads were reduced by $53 \%$ to $\mathrm{SL}_{\mathrm{Q}-00 \mathrm{~s}}=9.3 \mathrm{Mg} / \mathrm{ha}$, and the main part still took place during the IS as before $\left(74 \%\right.$; SL $\left.\mathrm{Q}_{\mathrm{Q}-\mathrm{IS}-00 \mathrm{~s}}=24545 \mathrm{Mg} / \mathrm{ha}\right)$.

Table 5. Average mass of salt loads ( $S_{Q}$; Mg/yr) exported through La Violada Gully during the Non Irrigation Season, the Irrigation Season (seasonal percent in brackets), and the hydrologic year (with its percent increase over the surface irrigation period; $\Delta_{/ 90 s}$ ) for the surface irrigation (1995-98), pre-works (2005-07) and sprinkler irrigation (2011-15; separating 2011-12 and 201315) periods.

MASS OF SALT LOADS $\left(\mathrm{S}_{\mathrm{Q}} ; \mathrm{Mg} / \mathrm{yr}\right)$

\begin{tabular}{lcccc}
\hline Period & Non Irrigation Session & Irrigation Session & Hydrologic year & \multicolumn{1}{c}{$\Delta / 90 \mathrm{~s}$} \\
\hline Surface & $20815.7(28 \%)$ & $53443.4(72 \%)$ & 74259.1 & \\
Pre-works & $8673.7(26 \%)$ & $24545.5(74 \%)$ & 33219.1 & $-55.3 \%$ \\
Sprinkler & $12685.9(43 \%)$ & $16684.2(57 \%)$ & 29370.1 & $-60.4 \%$ \\
\hline $\mathbf{2 0 1 1 - 1 2}$ & $6534.1(42 \%)$ & $8887.4(58 \%)$ & 15421.5 & \\
$\mathbf{2 0 1 3 - 1 5}$ & $16787.1(43 \%)$ & $21882(57 \%)$ & 38669.1 & \\
\hline
\end{tabular}

Under sprinkler irrigation salt loads decreased by $68 \%$ in relation to surface irrigation: $\mathrm{SL}_{\mathrm{Q}-10 \mathrm{~s}}=7.5 \mathrm{Mg} / \mathrm{ha}$ (Table 4). This decrease means a contribution from the VID of $\mathrm{S}_{\mathrm{Q}-10 \mathrm{~s}}$ $=29370 \mathrm{Mg} /$ year to the surface waters of the Ebro River Basin (Table 5). Most of the reduction in salt loads under sprinkler irrigation took place during the IS, resulting in similar exports during the IS (43\%) and the nIS (57\%), in contrast to the previous periods under surface irrigation (90s and 00s). 
Salt loads under sprinkler irrigation from VID were similar to other sprinkler irrigated areas at the Middle Ebro River Basin (between 5 and $7 \mathrm{Mg} / \mathrm{ha}$ ) without gypsum or salt substrates (Causapé, 2009; CITA-CHE, 2017; García-Garizábal and Causapé, 2010; Villar et al., 2015). Nevertheless, salt loads from other basins under sprinkler irrigation, with gypsum or salt substrate, were around 13-14 Mg/ha (CITA-CHE, 2017; Tedeschi et al., 2001). The new technologies and infrastructures at VID might be the cause of these differences with other irrigated districts of similar characteristics (sprinkler irrigated and with presence of gypsum or salts), but older than VID. However, salt loads from VID were lower in the first years after the transformation $\left(\mathrm{SL}_{\mathrm{Q}-11-12}=4.0 \mathrm{Mg} / \mathrm{ha}\right.$ or $\left.\mathrm{S}_{\mathrm{Q}-11-12}=15422 \mathrm{Mg} / \mathrm{yr}\right)$ than after the extreme rains of October $2012(9.8 \mathrm{Mg} / \mathrm{ha}$ or 38669 $\mathrm{Mg} / \mathrm{yr}$; Table 5). The $\mathrm{SL}_{\mathrm{Q}}$ after this rain were more similar to those found by other authors in similar districts, suggesting that the lower $\mathrm{SL}_{\mathrm{Q}}$ in 2011-12 may have been caused by the temporary accumulation of salts after the partial destruction of the drainage system and the reduction in I with the new irrigation system.

\subsubsection{Salt Balance}

The ANOVA for the SB showed significant differences $(\mathrm{P}<0.05)$ between the 90 s and the 00s and 10s, with no differences between them. Under surface irrigation, the SB reached values of $\mathrm{SB}_{90 \mathrm{~s}}=-16.7 \mathrm{Mg} / \mathrm{ha}$ (Table 4), but during the pre-works period, it dropped (in absolute terms) to $\mathrm{SB}_{00 \mathrm{~s}}=-7.5 \mathrm{Mg} / \mathrm{ha}(-55 \%)$. Finally, the $\mathrm{SB}$ decreased to $\mathrm{SB}_{10 \mathrm{~s}}=-5.6 \mathrm{Mg} / \mathrm{ha}$ under sprinkler irrigation $(66 \%$ decrease compared to surface irrigation) showing a higher variability (high SD) due to the October 2012 precipitation event.

Under surface irrigation, $70 \%$ of the annual leaching took place during the IS due to excess I (high volume and low frequency) and CS (Fig. 4). Both terms decreased noticeably in the pre-works period, but leaching still took place mainly during the IS (71\%). Under sprinkler irrigation, the SB became evenly distributed throughout the year: $53 \%$ during the nIS and $47 \%$ in IS, this situation was also described by Tedeschi et al. (2001) in other sprinkler irrigation district in the Ebro River Basin.

However, the extreme precipitation event of October 2012 induced a change in the seasonality of the SB under sprinkler irrigation. In the first sprinkler irrigation years 
(2011-12), SB took place especially during the nIS (64\%; Fig. 4) while for 2013-15, the SB became equal for both seasons (51\% in the nIS and $49 \%$ in the IS).

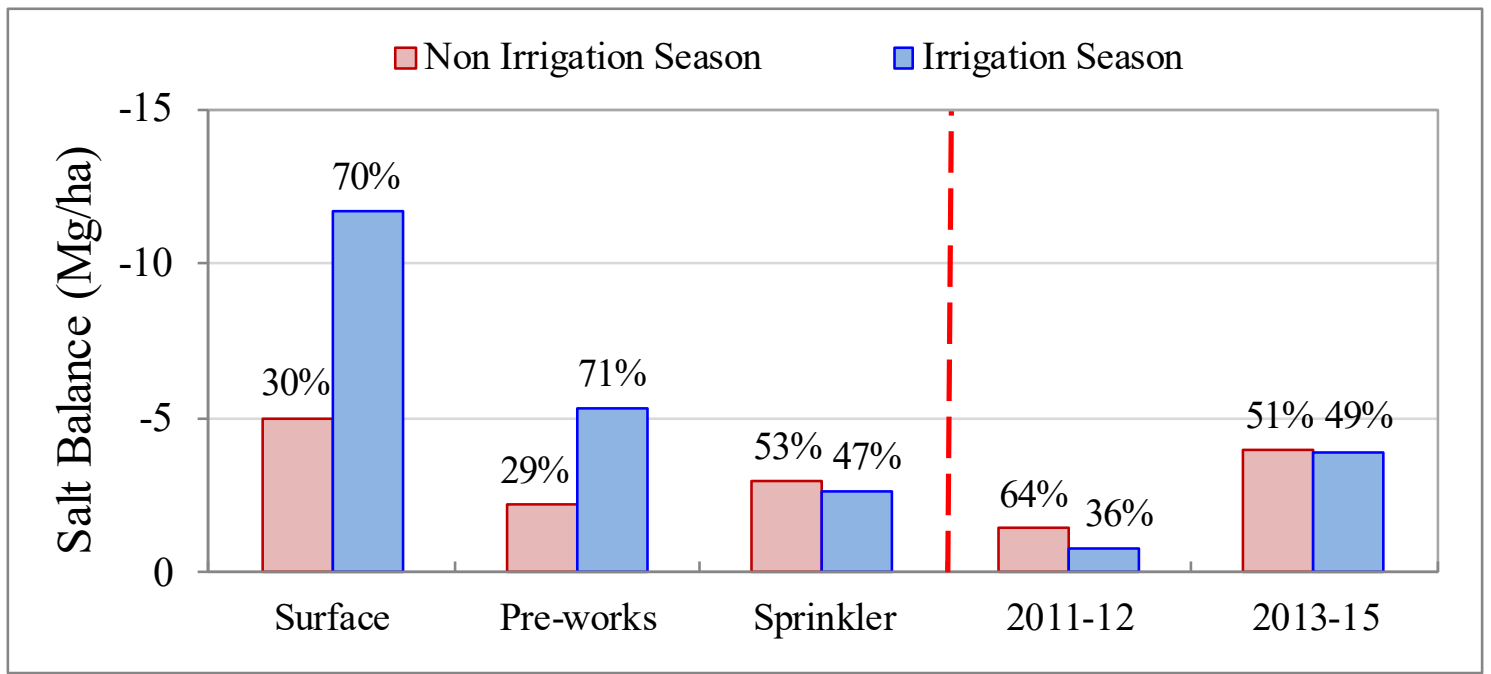

Fig. 4. Salt balance in VID: comparative for the Non Irrigation Season (nIS) and Irrigation Season (IS) for the surface irrigation (1995-98), pre-works (2005-07) and sprinkler irrigation (2011-15) periods, differentiating the two phases in sprinkler irrigation (2011-12 and 2013-15) produced by the October $20^{\text {th }} 2012$ precipitation event.

Monthly averages of SB (Fig. 2b) confirm changes in the seasonal patterns as observed in $\mathrm{Q}$ (Table 3a) and $\mathrm{SL}_{\mathrm{Q}}$ (Table 4). The SB was significantly higher (i.e. less leaching, as $\mathrm{SB}<0$ ) under sprinkler than surface irrigation, from March to September (Fig. 2b).

\subsubsection{Risk of Soil Salinization}

$\mathrm{SB}$ values close to zero $\left(\mathrm{SL}_{\mathrm{IN}} \sim \mathrm{SL}_{\mathrm{Q}}\right)$ may indicate scarce leaching and risk of soil salinization The irrigation doses needed to provide enough salt leaching depend on irrigation water quality, crops and soil hydrological characteristics (Bos and Wolters, 1994). Even irrigation districts with high water quality (such as the Monegros Canal; $\mathrm{EC}<1 \mathrm{dS} / \mathrm{m}$ ) may be subject to salinization without an adequate irrigation management providing the necessary salt leaching (Bos and Wolters, 1994; Van Hoorn and Van Alphen, 1994).

The SB was negative in all periods (outputs $>$ inputs) ensuring no soil salinization of the VID as a whole, so far. It could be expected that the lower I under sprinkler irrigation, might lead to insufficient leaching and salt accumulation $(\mathrm{SB}>0)$. But, until now, this situation has not arisen. Nevertheless, it is essential to monitor the SB at an irrigated semiarid zone as this, when the irrigation volume is decreased, like under the new scenario of sprinkler irrigation. 
The simple regression between water inputs $(\mathrm{I}+\mathrm{P})$ and $\mathrm{SB}$, allows for estimating the minimum water inputs $(\mathrm{I}+\mathrm{P})$ needed to ensure the salt leaching and avoid soil salinization (Bos, 2004). The regression on Fig. 5 shows a minimum water input of $6436 \mathrm{~m}^{3} / \mathrm{ha}$ in VID to avoid salinization. Considering the $458 \mathrm{~mm}$ of average precipitation ( $\left.4584 \mathrm{~m}^{3} / \mathrm{ha}\right)$, a minimum $1856 \mathrm{~m}^{3} /$ ha of annual I is needed at VID as a rough approximation.

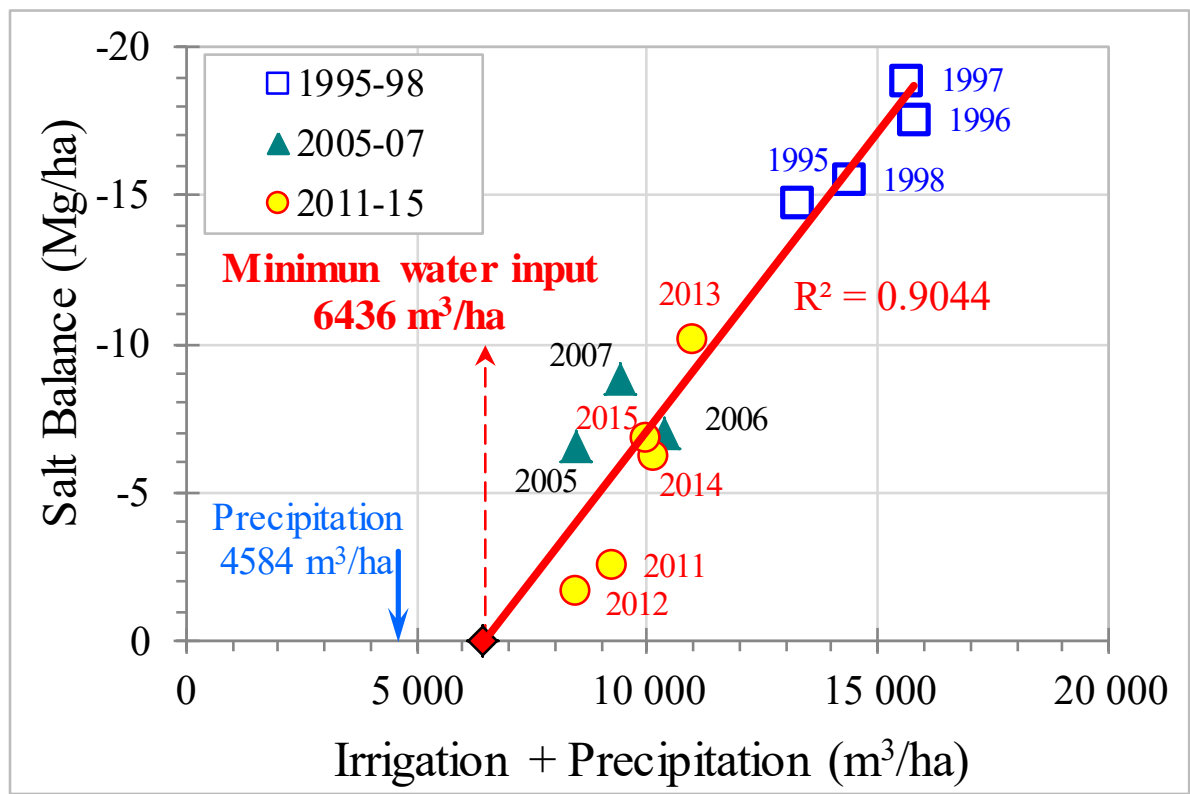

Fig. 5. Annual water input (Irrigation plus Precipitation) and salt balance (absolute value) in the VID for the surface (1995-98), pre-works (2005-08) and sprinkler irrigation (2011-15) periods; and linear regression to estimate the minimum water input required to ensure salt leaching.

As indicated, the annual SB has not pointed to risk of soil salinization in VID so far, but the monthly SB was slightly positive in July and August 2012, and very close to zero in some other months in the IS 2011-12. From 2013 onwards, the SB has been negative every month, enough to avoid soil salinization, at district scale, if this trend is maintained.

\subsection{Nitrate Loads}

\subsubsection{Nitrate Concentration}

Nitrate concentrations $\left(\mathrm{NO}_{3}^{-}\right)$at the gauging station were not significantly different $(\mathrm{P}>0.05)$ in any of the three study periods (Table 6$)$ due to the high variability showed during surface and sprinkler irrigation (high $\mathrm{SD}$ ). The average $\mathrm{NO}_{3}{ }^{-}$concentration at pre and post modernization process were very similar to one another $\left(\mathrm{NO}_{3}{ }^{-}{ }_{90 \mathrm{~s}}=37 \pm 12 \mathrm{mg} / \mathrm{L}\right.$ and $\mathrm{NO}_{3}{ }^{-} 10 \mathrm{~s}=38 \pm 13 \mathrm{mg} / \mathrm{L}$ ) with a slightly increase of $3 \%$ in relation to surface irrigation. During pre-works period, this concentration, and its variability, decreased to $\mathrm{NO}_{3}{ }^{-} 00 \mathrm{~s}=21$ 
$\pm 0.7 \mathrm{mg} / \mathrm{L}(-42 \%)$ due to dominance of alfalfa, a crop with lower $\mathrm{N}$ fertilization requirements.

Table 6. Annual average of Nitrate Concentration $\left(\mathrm{NO}_{3} ; \mathrm{mg} / \mathrm{L}\right)$, Nitrate Loads per unit irrigated area $\left(N L_{Q} ; \mathrm{kg} / \mathrm{ha}\right)$ and Mass of Nitrate Loads $\left(N_{Q} ; M g / y r\right)$ at the gauging station (different letters means significant differences between periods; $P<0.05)$, standard deviation $(S D ; k g / h a)$, coefficient of variation $(\mathrm{CV} ; \%)$, and percent increase over surface irrigation $\left(\Delta_{900} ; \%\right)$ for the surface irrigation (1995-98), pre-works (2005-07) and sprinkler irrigation

NITRATE LOADS

\begin{tabular}{|c|c|c|c|c|c|c|}
\hline \multirow[b]{2}{*}{ Period } & \multicolumn{2}{|c|}{$\begin{array}{l}\text { Nitrate Concentration } \\
\qquad\left(\mathrm{NO}_{3}^{-}, \mathrm{mg} / \mathrm{L}\right)\end{array}$} & \multicolumn{2}{|c|}{$\begin{array}{l}\text { Outflow Nitrate Loads } \\
\quad\left(N L_{Q} ; \mathrm{kg} \mathrm{N} / \mathrm{ha}\right)\end{array}$} & \multicolumn{2}{|c|}{$\begin{array}{l}\text { Mass of Nitrate Loads } \\
\quad\left(N_{Q} ; M g N / y r\right)\end{array}$} \\
\hline & Mean \pm SD & $\Delta_{/ 90 \mathrm{~s}}$ & Mean \pm SD & $\Delta / 90 \mathrm{~s}$ & Mean $\pm \mathrm{SD}$ & $\Delta_{/ 90 \mathrm{~s}}$ \\
\hline Surface & $36.9 \mathrm{a} \pm 12.0$ & & $114.3 \mathrm{a} \pm 37.1$ & & $427.4 \pm 141.4$ & \\
\hline Pre-works & $21.3 \mathrm{a} \pm 0.7$ & $-42 \%$ & $23.9 b \pm 3.6$ & $-79 \%$ & $90.4 \pm 14.6$ & $-78.8 \%$ \\
\hline Sprinkler & $37.9 \mathrm{a} \pm 13.1$ & $3 \%$ & $32.1 \mathrm{~b} \pm 19.4$ & $-72 \%$ & $126.5 \pm 77.5$ & $-70.4 \%$ \\
\hline
\end{tabular}

During the $90 \mathrm{~s}$, an average of 76.3 days per year registered $\mathrm{NO}_{3}{ }^{-}$concentrations over the limit of $50 \mathrm{mg} / \mathrm{L}$. The year with more days above the limit was 1998 (139 days) while only 18 days had $\mathrm{NO}_{3}{ }^{-}$concentrations above $50 \mathrm{mg} / \mathrm{L}$ in 1995 . During the pre-works period (00s), the number of days above the $\mathrm{NO}_{3}{ }^{-}$limit reduced to 4 days/year, mainly due to corn substitution by alfalfa as main crop and, secondly, possibly to the increase of fertilizer prices.

The sprinkler irrigation period (2011-15) presented more days above the limit $(90.6$ days/year) than the surface irrigation period. The year with more days with $\mathrm{NO}_{3}{ }^{-}$ concentration above $50 \mathrm{mg} / \mathrm{L}$ was 2015 (202 days). Nevertheless the first two years with sprinkler irrigation (2011-12), only 12.5 days/year had $\mathrm{NO}_{3}{ }^{-}$concentrations above $50 \mathrm{mg} / \mathrm{L}$, while on the following years (2013-15) there was an average of 142.7 days/year above that limit. Again, this change in $\mathrm{NO}_{3}{ }^{-}$concentration was induced by the extreme rainfall event of October 2012.

The monthly averages of $\mathrm{NO}_{3}^{-}$under surface and sprinkler irrigation showed clearly graphical differences (Fig. 2c), with much lower concentrations in the 10s, especially for February and July when under surface irrigation the sidedress applications of cereal and corn were applied, respectively (Barros et al., 2012a and Isidoro et al 2006b). The differences for those months were not significant in the ANOVA tests due to the strong monthly variability of $\mathrm{NO}_{3}{ }^{-}$under surface irrigation; the only significant differences were found in June and September $(\mathrm{P}<0.05)$. Any high concentrations disappeared in the pre- 
works periods due to the alfalfa cultivation. The $\mathrm{NO}_{3}{ }^{-}$maximum under sprinkler irrigation was found in September, at the end of the hydrological year $(48.5 \mathrm{mg} / \mathrm{L})$, mainly induced by the longer crop cycle of double crops that delays fertilizer applications.

\subsubsection{Nitrate Loads}

Outflow nitrate loads $\left(\mathrm{NL}_{\mathrm{Q}}\right)$ were significantly higher in the $90 \mathrm{~s}$ than in the $00 \mathrm{~s}$ and $10 \mathrm{~s}$, without differences between them (Table 6). Annual $\mathrm{NL}_{\mathrm{Q}}$ under surface irrigation amounted to $\mathrm{NL}_{\mathrm{Q}-90 \mathrm{~s}}=114 \mathrm{~kg} \pm 37{\mathrm{~N}-\mathrm{NO}_{3}}^{-}$/ha showing high variability between years, and following the high differences in $\mathrm{NO}_{3}{ }^{-}$. Those loads represented a high annual contribution of $\mathrm{N}_{\mathrm{Q}-90 \mathrm{~s}}=427{\mathrm{Mg} \mathrm{N}-\mathrm{NO}_{3}}^{-} / \mathrm{yr}$, due to crop management, especially corn. A good deal of the pre-sowing $\mathrm{N}$ fertilization to corn was lost due to need of pre-sowing irrigations to avoid crust formation and the same happened with sidedress applications (directly applied at the plot water intake and lost due to the low irrigation efficiency) (Barros et al., 2012a; Isidoro et al., 2006b).

During the pre-works period, a drastic reduction of $79 \%$ in $\mathrm{NL}_{\mathrm{Q}}$ took place due to the reduction in $\mathrm{NO}_{3}{ }^{-}$concentration and especially $\mathrm{Q}$ at the gauging station $\left(\mathrm{NL}_{\mathrm{Q}-00 \mathrm{~s}}=24 \mathrm{~kg}\right.$ $\mathrm{N}-\mathrm{NO}_{3} /$ ha; or $\mathrm{N}_{\mathrm{Q}-00 \mathrm{~s}}=90 \mathrm{Mg} / \mathrm{yr}$; Table 6). As with the $\mathrm{NO}_{3}{ }^{-}$, the variability along this period was lower than for the $90 \mathrm{~s}$ or $10 \mathrm{~s}$ due to the dominance of alfalfa. The results from the 90 s period (and to a lesser extent those from the pre-works period, 00s) compare well with other low-efficiency, surface irrigated districts from the Middle Ebro River Basin with $\mathrm{N}$ loads ranging from 23 to $119 \mathrm{~kg} \mathrm{N-N_{3 }}{ }^{-}$/ha per year (Causapé et al., 2004; GarcíaGarizábal et al., 2012).

Under sprinkler irrigation, $\mathrm{NL}_{\mathrm{Q}}$ rose slightly to $\mathrm{NL}_{\mathrm{Q}-10 \mathrm{~s}}=32 \pm 19 \mathrm{~kg} \mathrm{~N}-\mathrm{NO}_{3} /$ ha; with a higher variability between years. These loads were similar to those found by Cavero et al. (2003) in an irrigation district of Monegros II. The NLQ under sprinkler irrigation were $72 \%$ lower than under surface irrigation, even though both periods had similar, high crop intensity (dominance of corn and/or double crops). From 2013, an increase in NLQ on September and October is observed, probably due to the introduction of the double crops and the full operation of AWUA, added to the extremely precipitation in October 2012.

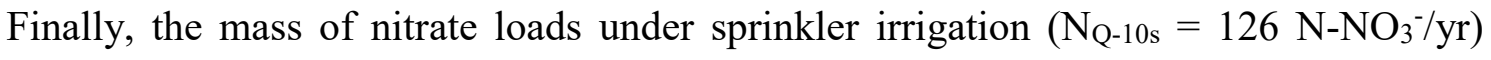

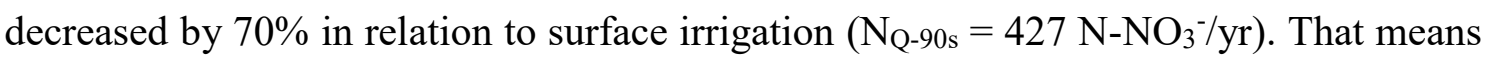
a reduction of $301 \mathrm{Mg} \mathrm{N}-\mathrm{NO}_{3}{ }^{-}$in the $\mathrm{N}$ contribution of VID to the surface waters of the 
Ebro River Basin, despite the higher $\mathrm{NO}_{3}{ }^{-}$concentrations and the higher number of days with $\mathrm{NO}_{3}{ }^{-}$above the limit of $50 \mathrm{mg} / \mathrm{L}$ after modernization.

\subsection{Salt Balance and Nitrate Loads Factorial Analysis}

The factor analysis of the salt balance (S-FA) and of the nitrate loads (N-FA) showed that $95.9 \%$ and $94.4 \%$ of the variance, respectively, was explained by 3 independent factors: Flow Factor, Crop Factor and Concentration Factor.

The Flow factor accounted for $60.2 \%$ of the variance in the S-FA and for $61.8 \%$ in the NFA. It was positively related to the variables I and Q (Fig. 6a and c), showing a close relationship between I applied and Q produced (Duncan et al. 2008). In the S-FA, I and Q are negatively linked to SB (negative): higher I led to higher Q and to lower SB (more salt leaching). In the same way, the N-FA showed the positive relation between I, Q and $\mathrm{NL}_{\mathrm{Q}}$ : the higher any of them, the higher the others. Less irrigation implied that the salt leaching (with lower differences between $\mathrm{SL}_{\mathrm{IN}}$ and $\mathrm{SLQ}$ ) and the nitrate leaching from the system were highly reduced.

The Crop Factor $(23.7 \%$ of the variance in S-FA and $20.2 \%$ in N-FA) was linked (positive for S-FA and negative for N-FA) to alfalfa cropped area (and to a lesser extend to cereal) and opposed to corn area (as sum of corn and double crop of corn; Fig. 6a and c). The variables linked to this factor just point to the evident relationship between cropped areas to different crops (more corn, means less alfalfa and vice versa); but the independence of this Crop Factor from the Flow Factor points out that crop patterns were not the main determinant of $\mathrm{I}$ and $\mathrm{Q}$ (and therefore $\mathrm{SB}$ and $\mathrm{NL}_{\mathrm{Q}}$ ) in the study years, rather than the irrigation system. Cereal is not especially linked to any factor, but as in S-AF, it was opposed to corn and also to $\mathrm{NO}_{3}{ }^{-}$(the more cereal cropped, the less corn and the less nitrogen fertilization applied).

The Concentration Factor was positively correlated with $\mathrm{TDS}_{\mathrm{Q}}$ and $\mathrm{NO}_{3}{ }^{-}$respectively for each factor analysis. It accounted for $12.0 \%$ of the total variance in S-FA and $12.5 \%$ in N-FA. The independence with the other two factors implies some independence of the drainage concentration from the irrigation system and crop pattern in special for $\mathrm{NO}_{3}{ }^{-}$, but the $\mathrm{TDS}_{\mathrm{Q}}$ was related negatively (slightly) with the Flow Factor pointing to a strong dilution effect during 1995-98 years. 


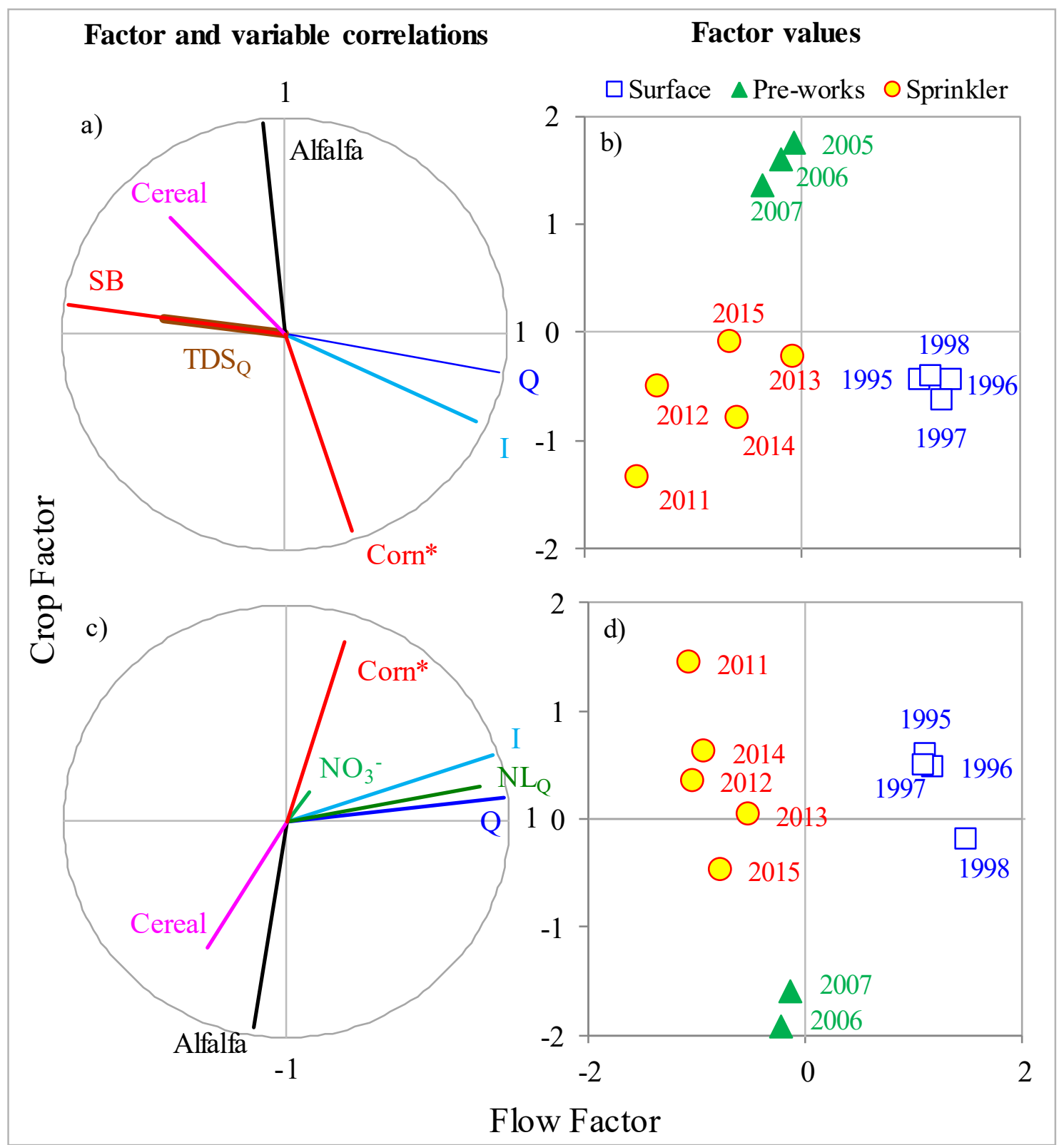

Fig. 6. Factor Analysis for the Salt $(a \& b)$ and Nitrate $(c \& d)$ loads in VID: $(a \& c)$ coefficients of correlation between the 2 first factors and the variables [percent area of the main crops: Cereal, Alfalfa and corn plus double crops (Corn*), irrigation (I), and outflow (Q); salt balance $(S B)$ and TDS concentration (TDS) for the salt load analysis and nitrate load $\left(N L_{Q}\right)$ and concentration $\left(\mathrm{NO}_{3}{ }^{-}\right)$for the nitrate load analysis]; $(b \& d)$ scatter diagram of the study years on the plane of the two main factors.

The correlation between factors and variables (Fig. 6a and c) showed some positive correlation of corn with I and Q, while alfalfa was practically independent, possibly due to the high alfalfa acreage with scarce irrigation during 2005-07 (due to the uncertainty previous to the modernization works). Cereal was slightly correlated, negatively, with I and Q due to its low water requirements (compared to corn and alfalfa). The SB and the $\mathrm{NL}_{\mathrm{Q}}$ was clearly determined by $\mathrm{Q}$ and strongly linked to $\mathrm{I}$. 
The study years were grouped in the plane of the two first factors (Fig. 6b and d). The surface irrigation years were mainly characterized by high I and Q, so they are located to the positive side of the Flow Factor axis for both factor analyses against the sprinkler years at the minor side of the axis due to the low I and Q. But both periods showed similar values of the Crop Factor due to corn dominance in 1995-98 and 2011-15. Nevertheless, the pre-works period is characterized by the alfalfa dominance so it is located on the positive side of the Crop Factor axis for S-FA and on the negative side for N-FA but also slightly to the negative side of the Flow Factor, due to the low I and Q along 2005-08 (Fig. 6b).

So, three clusters were clearly plotted for the three periods. Surface and pre-works periods presented narrow clusters as their main characteristics were high I and Q (more than the crop) for the surface period and the alfalfa area for the pre-works. However, the sprinkler irrigation years were characterized mainly by the reduction of I, Q, SB (absolute values) and $\mathrm{NL}_{\mathrm{Q}}$, but also by the recovery of the corn cropped area with more influence on the $\mathrm{SB}$ and specially on $\mathrm{NL}_{\mathrm{Q}}$, than under surface irrigation, so they were spread over the entire third quadrant for the S-FA and over the second for the N-FA.

The independence of the Concentration Factor, represented by $\mathrm{TDS}_{\mathrm{Q}}$ and $\mathrm{NO}_{3}{ }^{-}$ respectively, showed the weak influence of these concentrations on the $\mathrm{SB}$ and $\mathrm{NL}_{\mathrm{Q}}$, as compared to I and Q. The total mass of salts and nitrogen exported were more influenced by the total volume of irrigation (which determined the volume of outflows) than by the concentration of the outflows. Nevertheless, the N-FA has shown a slight relationship of $\mathrm{NO}_{3}{ }^{-}$with corn surface (the crop with highest nitrogen requirements).

\subsection{Hydrological and agronomical indices}

The Drainage Fraction (DF) and Consumptive Fraction (CF) have shown significant differences $(\mathrm{P}<0.05)$ between the three study periods (Table 7). The Irrigation Efficiency (IEf; calculated just for the IS) presented differences between surface irrigation and the pre-works and sprinkler periods, without differences between them.

During surface irrigation, the $\mathrm{DF}_{90 \text { s }}$ reached $61 \%$ with low variability (Table 7 ) which can be seen too in Fig. 7. In the pre-works period, DF decreased by $36 \%$ to $\mathrm{DF}_{00 \mathrm{~s}}=39 \%$ due to lower CS, irrigation restrictions and changes in crop patterns. In the $00 \mathrm{~s}$, the 
variability between years was slightly higher due to the relative minimum in 2005 $\left(\mathrm{DF}_{05}=25 \%\right)$ caused by the drought of 2005 . Finally, sprinkler irrigation reduced the $\mathrm{DF}_{10 \text { s }}$ to $23 \%$ what means a reduction of $62 \%$ in regard to surface irrigation but showing a much higher variability. The decrease in seasonal DF culminated in 2012 with a historical minimum of $\mathrm{DF}_{12}=8 \%$ corresponding to a new drought. In 2013, DF presented a new relative maximum $\left(\mathrm{DF}_{13}=27 \%\right)$ caused by the extreme precipitation in October 2012. In the flowing years, the DF apparently stabilized around $20 \%$.

Table 7. Hydrological indices (\%) for the irrigation season in the VID of the surface irrigation (1995-98), pre-works (2005-08) and sprinkler irrigation (2011-15) periods: Drainage Fraction $(D F)$, Consumptive Fraction $(C F)$ and Irrigation Efficiency (IEf) (different letters mean significant differences between periods; $P<0.05)$, standard deviation $(S D)$ and percent increase over surface irrigation $\left(\Delta_{/ 90 s} ; \%\right)$.

HYDROLOGICAL INDICES (\%)

\begin{tabular}{|c|c|c|c|c|c|c|c|c|c|}
\hline \multirow[b]{2}{*}{ Period } & \multicolumn{3}{|c|}{$\begin{array}{c}\text { Drainage Fraction } \\
(\mathrm{DF})\end{array}$} & \multicolumn{3}{|c|}{$\begin{array}{l}\text { Consumtive Fraction } \\
\qquad(\mathrm{CF})\end{array}$} & \multicolumn{3}{|c|}{$\begin{array}{c}\text { Irrigation Efficiency } \\
\text { (IEf) }\end{array}$} \\
\hline & Mean & $\pm \mathrm{SD}$ & $\Delta_{/ 90 \mathrm{~s}}$ & Mean & $\pm \mathrm{SD}$ & $\Delta_{/ 90 \mathrm{~s}}$ & Mean & $\pm \mathrm{SD}$ & $\Delta_{/ 90 \mathrm{~s}}$ \\
\hline Surface & $61.0 \mathrm{a}$ & \pm 2.2 & & $51.0 \mathrm{a}$ & \pm 3.0 & & 55.8 a & $a \pm 3.6$ & \\
\hline $\begin{array}{l}\text { Pre- } \\
\text { works }\end{array}$ & $38.8 \mathrm{~b}$ & \pm 8.3 & -36 & $64.9 \mathrm{~b}$ & \pm 3.5 & 27 & $69.6 \mathrm{~b}$ & $b \pm 4.5$ & 25 \\
\hline Sprinkler & $23.4 \mathrm{c}$ & \pm 12.4 & -62 & $88.5 \mathrm{c}$ & \pm 5.0 & 73 & $80.0 \mathrm{~b}$ & $b \pm 5.5$ & 43 \\
\hline
\end{tabular}

The crop water consumption, represented by $\mathrm{CF}$, increased from $\mathrm{CF}_{90 \mathrm{~s}}=51 \%$ to $\mathrm{CF}_{00 \mathrm{~s}}=65 \%(27 \%)$ during the pre-works period (Table 7). After modernization, the CF increased to $\mathrm{CF}_{10 \mathrm{~s}}=89 \%(73 \%)$, showing a maximization of irrigation water use as postulated by other authors from several modernization scenarios (Lecina et al. 2010). As opposed to the DF, the seasonal CF showed a gradual increase from a minimum in 1997 $\left(\mathrm{CF}_{97}=51 \%\right.$; Fig. 7$)$ to a maximum in 2011 over $100 \%\left(\mathrm{CF}_{11}=104 \%\right)$ following the implementation of different improvements in the irrigation system. In the following years, the CF remained around 93-99\%.

The maximization of water use in VID after the 00 s produced an increase in IEf of $25 \%$ in relation to the surface irrigation period, from $\mathrm{IEf}_{90 \mathrm{~s}}=56 \%$ to $\operatorname{IEf}_{00 \mathrm{~s}}=70 \%$ (Table 7). During the pre-works period, and linked to the DF, a new relative maximum occurred during the drought year of $2005\left(\operatorname{IEf}_{05}=75 \%\right)$. After the modernization works, the IEf reached its maximum average values: $\mathrm{IEf}_{10 \mathrm{~s}}=80 \%(+43 \%$ compared to surface irrigation), with a seasonal maximum around 90\% in 2011 and 2013 (as in CF). But this 
increase maybe were compromised by the possible over/underestimation of the $\mathrm{ET}_{\mathrm{a}}$ calculations for surface or sprinkler irrigation. Nevertheless, this efficiency places VID as one of the irrigation districts with better IEf in the Ebro River Basin as compared to other irritation districts with both surface and sprinkler irrigation systems, with efficiencies ranging from $64 \%$ to $73 \%$ (CITA-CHE, 2017).

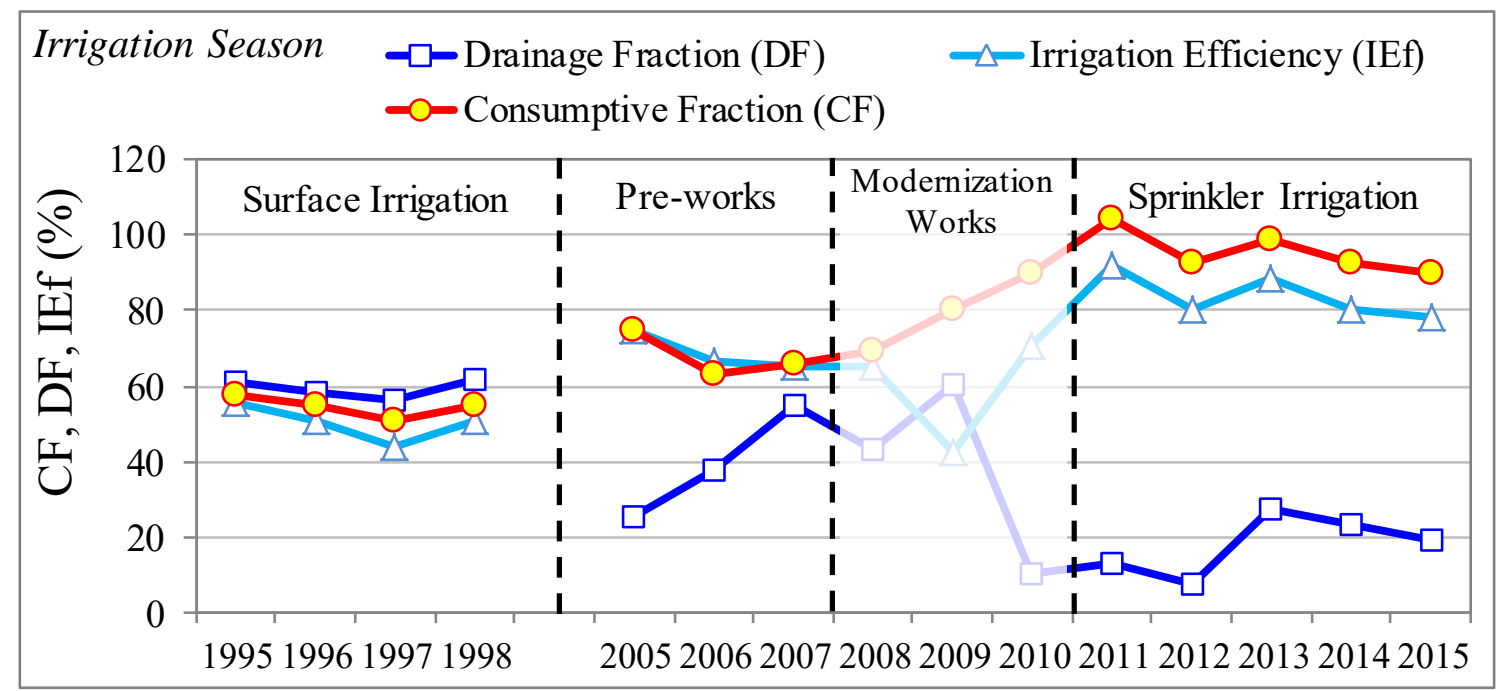

Fig. 7. Average hydrological indices for the irrigation season in the study years: Drainage Fraction (DF), Consumptive Fraction (CF) and Irrigation Efficiency (IEf).

\section{CONCLUSIONS}

Under cropping patterns of similar intensity, the water diverted for irrigation at La Violada Irrigation District (VID) was directly linked to the irrigation system. The modernization of the irrigation system in the Almudévar Water User Association (AUWA) and other previous improvements resulted in savings of $19 \mathrm{hm}^{3} / \mathrm{yr}$ of high quality water, now available for other uses downstream. Modernization to sprinkler irrigation has led to a better use of water resources, significantly increasing the hydrological and agronomical indices. Furthermore, the lower flows (I and Q) and their pollutant concentrations so far similar to pre-modernization scenario, have caused a reduction of salt and nitrate loads to La Violada Gully and hence to the Ebro River. But the growing nitrate concentration, suggests that the new flow rate after modernization does not provide enough dilution to maintain $\mathrm{N}-\mathrm{NO}_{3}{ }^{-}$concentration below the legal limits established by the European Union $(50 \mathrm{mg} / \mathrm{L})$. Also, the salt balance in the VID proved that, at the moment, there is no risk of soil salinization due to scarce irrigation or salt leaching. 


\section{ACKNOWLEDGEMENTS}

This work was funded by the Spanish Ministry of Science and Innovation through the research grants AGL2010-21681-C03-03 and AGL2013-48728-C2-2-R, the European Reginal Development Fund (FEDER) and the Ebro River Basin Authority through a collaboration agreement. Thanks are given to the Almudévar Water User Association and the Ebro River Basin Authority for their support.

\section{REFERENCES}

Alarcón, J., Garrido, A., Juana, L., 2016. Modernization of irrigation systems in Spain: review and analysis for decision making. International Journal of Water Resources Development, 32, 442-458.

Allen, R.G., Clemmens, A.J., Burt, C.M., Solomon, K., O’Halloran, T., 2005. Prediction Accuracy for Projectwide Evapotranspiration Using Crop Coefficients and Reference Evapotranspiration. Journal of Irrigation and Drainage Engineering, 131, 24-36.

Allen, R.G., Pereira, L.S., Raes, D., Smith, M., 1998. Crop evapotranspiration-Guidelines for computing crop water requirements-FAO Irrigation and drainage paper 56. FAO, Rome, 300, D05109.

Aragüés, R., Tanji, K.K., 2003. Water quality of irrigation return flows. In: Stewart, B.A., Howell, T.A. (Eds.), Encyclopedia of Water Science. Marcel Dekker, New York, USA, pp. 502-506.

Ayers, R.S., Westcot, D.W., 1985. Water quality for agriculture. FAO Irrig. and Drain. Paper n²9 Rev. 1, Rome, Italy, pp. 174.

Barros, R., Isidoro, D., Aragüés, R., 2011a. Long-term water balances in La Violada irrigation district (Spain): I. Sequential assessment and minimization of closing errors. Agricultural Water Management, 102, 35-45. 
Barros, R., Isidoro, D., Aragüés, R., 2011b. Long-term water balances in La Violada Irrigation District (Spain): II. Analysis of irrigation performance. Agricultural Water Management, 98, 1569-1576.

Barros, R., Isidoro, D., Aragüés, R., 2012a. Irrigation management, nitrogen fertilization and nitrogen losses in the return flows of La Violada irrigation district (Spain). Agriculture Ecosystems \& Environment, 155, 161-171.

Barros, R., Isidoro, D., Aragüés, R., 2012b. Three study decades on irrigation performance and salt concentrations and loads in the irrigation return flows of $\mathrm{La}$ Violada irrigation district (Spain). Agriculture Ecosystems \& Environment, 151, 44-52.

Berbel, J., Gutiérrez-Martín, C., Rodríguez-Díaz, J.A., Camacho, E., Montesinos, P., 2015. Literature Review on Rebound Effect of Water Saving Measures and Analysis of a Spanish Case Study. Water Resources Management, 29, 663-678.

Bos, M.G., Bastiaanssen, W.G.M., 2004. Using the depleted fraction to manage the groundwater table in irrigated areas. Irrigation and Drainage Systems, 18, 201209.

Bos, M.G., Wolters, W., 1994. Influences of Irrigation on Drainage. In: Ritzema, H. (Ed.), Drainage principles and applications. Ed. 2 ILRI Publication 16, Wageningen, The Netherlands, pp. 513-530.

Burt, C.M., Clemmens, A.J., Strelkoff, T.S., Solomon, K.H., Bliesner, R.D., Hardy, L.A., Howell, T.A., Eisenhauer, D.E., 1997. Irrigation performance measures: Efficiency and uniformity. Journal of Irrigation and Drainage Engineering-Asce, $123,423-442$.

Carpenter, S.R., Caraco, N.F., Correll, D.L., Howarth, R.W., Sharpley, A.N., Smith, V.H., 1998. Nonpoint pollution of surface waters with phosphorus and nitrogen. Ecological applications, 8, 559-568.

Causapé, J., 2009. Agro-environmental evaluation of irrigation land: II. Pollution induced by Bardenas Irrigation District (Spain). Agricultural Water Management, 96, 188194. 
Cavero, J., Beltrán, Á., Aragüés, R., 2003. Nitrate Exported in Drainage Waters of Two Sprinkler-Irrigated Watersheds. Journal of Environmental Quality, 926, 916-926.

CITA-CHE, 2017. Evaluación de la afección al estado de las masas de agua superficiales por los retornos de riego de cuatro sistemas de la cuenca del ebro. Informe final del convenio de colaboración entre la Confederación Hidrográfica del Ebro (CHE) y el Centro de Investigación y Tecnología Agroalimentaria de Aragón (CITADGA), años 2013-15. pp. 355.

Clemmens, A.J., 2008. Accuracy of project-wide water uses from a water balance: a case study from Southern California. Irrigation and Drainage Systems, 22, 287-309.

De los Ríos, F., 1966. Colonización de las Bardenas, Cinco Villas, Somontano y Monegros, Sección de estudios agrícolas (3). Institución" Fernando el Católico", Zaragoza, Spain, pp. 56.

Duncan, R., Bethune, M., Thayalakumaran, T., Christen, E., McMahon, T., 2008. Management of salt mobilisation in the irrigated landscape-A review of selected irrigation regions. Journal of Hydrology, 351, 238-252.

Faci, J.M., Aragüés, R., Alberto, F., Quílez, D., Machín, J., Arrúe, J.L., 1985. Water and salt balance in an irrigated area of the Ebro River Basin (Spain). Irrigation Science, 6, 29-37.

FAO, 2002. Crops and drops, making the best use of water for agriculture. Natural Resources Management and Environment Department. FAO, Roma (Italy), pp. 28.

Fernández-García, I., Rodríguez-Díaz, J.A., Camacho-Poyato, E., Montesinos, P., Berbel, J., 2014. Effects of modernization and medium term perspectives on water and energy use in irrigation districts. Agricultural Systems, 131, 56-63.

García-Garizábal, I., Causapé, J., 2010. Influence of irrigation water management on the quantity and quality of irrigation return flows. Journal of Hydrology, 385, 36-43. 
Gómez-Lanuza, J., 2016. Efectos de la modernización de los regadíos en la Comunidad de Regantes de Almudévar (Huesca). Universidad de Zaragoza, Zaragoza, pp. 103.

Gómez-Ferrer, R., Hendricks, D.W., Turner, C.D., 1983. Salt Transport by the South Platte River in Northeast Colorado. Journal of the American Water Resources Association, 19, 183-190.

Harman, H.H., 1967. Modern factor analysis. 2nd ed. Oxford, England: Univ. of Chicago Press, pp. 474.

Isidoro, D., Quílez, D., Aragüés, R., 2004. Water balance and irrigation performance analysis: La Violada irrigation district (Spain) as a case study. Agricultural Water Management, 64, 123-142.

Isidoro, D., Quílez, D., Aragüés, R., 2006a. Environmental impact of irrigation in La Violada District (Spain): I. Salt export patterns. Journal of Environmental Quality, $35,766-775$.

Isidoro, D., Quílez, D., Aragüés, R., 2006b. Environmental impact of irrigation in La Violada District (Spain): II. Nitrogen fertilization and nitrate export patterns in drainage water. Journal of Environmental Quality, 35, 776-785.

ITGE, 1995a. Mapa geológico de España, Hoja n²85, Almudévar. Instituto tecnológico geominero de España, Madrid.

ITGE, 1995b. Mapa geológico de España, Hoja n³23, Zuera. Instituto tecnológico geominero de España, Madrid.

Jiménez-Aguirre, M.T., 2017. Impacto de la modernización del regadío sobre la cantidad y calidad de los retornos de riego. PhD Thesis, Universidad de Zaragoza and Centro de Investigación y Tecnología Agroalimentaría de Aragón, Zaragoza, 236 pp.

Jiménez-Aguirre, M.T., Isidoro, D., Usón, A., 2018a. Soil variability in La Violada Irrigation District (Spain): I Delineating soil units for irrigation. Geoderma, 311, 78-90. 
Jiménez-Aguirre, M.T., Isidoro, D., Usón, A., 2018b. Soil variability in La Violada Irrigation District (Spain): II Characterizing hydrologic and salinity features. Geoderma, 311, 67-77.

Lecina, S., Isidoro, D., Playán, E., Aragüés, R., 2010a. Irrigation modernization and water conservation in Spain: The case of Riegos del Alto Aragón. Agricultural Water Management, 97, 1663-1675.

Lecina, S., Isidoro, D., Playán, E., Aragüés, R., 2010b. Irrigation Modernization in Spain: Effects on Water Quantity and Quality-A Conceptual Approach. International Journal of Water Resources Development, 26, 265-282.

Li, X., Hu, C., Delgado, J.A., Zhang, Y., Ouyang, Z., 2007. Increased nitrogen use efficiencies as a key mitigation alternative to reduce nitrate leaching in north china plain. Agricultural Water Management, 89, 137-147.

Llamas, R., 1962. Estudio geológico-técnico de los terrenos yesíferos de la cuenca del Ebro y de los problemas que plantean en los canales. Servicio Geológico, Boletín no. 12 Informaciones y Estudios. Ministerio de Obras Públicas. Dirección General de Obras Hidráulicas, Madrid (Spain), pp. 192.

MARM - Ministerio de Medio Ambiente Medio Rural y Marino, 2002. Plan Nacional de Regadíos, $\quad$ http://www.mapama.gob.es/en/desarrollo-rural/temas/gestionsostenible-regadios/plan-nacional-regadios/texto-completo/.

MARM - Ministerio de Medio Ambiente Medio Rural y Marino, 2006. Plan de choque de modernización de regadíos, http://www.plandechoque-ahorrodeagua.es/.

MARM - Ministerio de Medio Ambiente Medio Rural y Marino, 2010. Estrategia Nacional para la Modernización Sostenible de los Regadíos, http://www.mapama.gob.es/es/calidad-y-evaluacion-ambiental/participacionpublica/pp 2009 p 019.aspx.

Perry, C., 2011. Accounting for water use: Terminology and implications for saving water and increasing production. Agricultural Water Management, 98, 1840-1846. 
Playán, E., Mateos, L., 2006. Modernization and optimization of irrigation systems to increase water productivity. Agricultural Water Management, 80, 100-116.

Playán, E., Salvador, R., Faci, J.M., Zapata, N., Martínez-Cob, A., Sánchez, I., 2005. Day and night wind drift and evaporation losses in sprinkler solid-sets and moving laterals. Agricultural Water Management, 76, 139-159.

Playán, E., Slatni, A., Castillo, R., Faci, J.M., 2000. A case study for irrigation modernisation: II Scenario analysis. Agricultural Water Management, 42, 335354.

Quemada, M., Baranski, M., Nobel-de Lange, M., Vallejo, A., Cooper, J., 2013. Metaanalysis of strategies to control nitrate leaching in irrigated agricultural systems and their effects on crop yield. Agriculture, ecosystems \& environment, 174, 110.

Rodríguez-Díaz, J.A., Pérez-Urrestarazu, L., Camacho-Poyato, E., Montesinos, P., 2011. The paradox of irrigation scheme modernization: more efficient water use linked to higher energy demand. Spanish Journal of Agricultural Research, 9, 1000-1008.

Scofield, C.S., 1940. Salt balance in irrigated areas. Journal of Agricultural Research, 61, 17-39.

Stambouli, T., Faci, J.M., Zapata, N., 2014. Water and energy management in an automated irrigation district. Agricultural Water Management, 142, 66-76.

Tanji, K.K., Kielen, N.C., 2002. Agricultural drainage water management in arid and semi-arid areas. FAO Irrigation and drainage paper 61. pp. 188.

Tedeschi, A., Beltrán, A., Aragüés, R., 2001. Irrigation management and hydrosalinity balance in a semi-arid area of the middle Ebro river basin (Spain). Agricultural Water Management, 49, 31-50.

Thayalakumaran, T., Bethune, M., McMahon, T.A., 2007. Achieving a salt balanceShould it be a management objective? Agricultural water management, 92, 1-12. 
UE - European Union, 2000. Directive 2000/60/CE of the European Parliament and of the Council of 23 October 2000 establishing a framework for Community action in the field of water policy. Off. J. Eur. Communities L327; 22/12/2000: 1-73.

Van Hoorn, J., Van Alphen, J., 1994. Salinity control. In: Ritzema, H. (Ed.), Drainage principles and applications., Wageningen, The Netherlands, pp. 533-600.

Villar, J.M., Pascual, M., Rufat, J., Villar, P., 2015. El impacto del riego en la calidad del agua de drenaje en una nueva zona regable. Ingeniería del agua, 19, 241-253.

Weisenburger, D.D., 1993. Human health effects of agrichemical use. Human Pathology, 24, 571-576. 